\title{
On the Use of Electromagnetics for Earth Imaging of the Polar Regions
}

\author{
Graham J. Hill ${ }^{1,2}$
}

Received: 30 November 2018 / Accepted: 19 August 2019 / Published online: 12 September 2019 (c) The Author(s) 2019

\begin{abstract}
The polar regions are host to fundamental unresolved challenges in Earth studies. The nature of these regions necessitates the use of geophysics to address these issues, with electromagnetic and, in particular, magnetotelluric studies finding favour and being applied over a number of different scales. The unique geography and climatic conditions of the polar regions means collecting magnetotelluric data at high latitudes, which presents challenges not typically encountered and may result in significant measurement errors. (1) The very high contact resistance between electrodes and the surficial snow and ice cover (commonly $\mathrm{M} \Omega$ ) can interfere with the electric field measurement. This is overcome by using custom-designed amplifiers placed at the active electrodes to buffer their high impedance contacts. (2) The proximity to the geomagnetic poles requires verification of the fundamental assumption in magnetotellurics that the magnetic source field is a vertically propagating, horizontally polarised plane wave. Behaviour of the polar electro-jet must be assessed to identify increased activity (high energy periods) that create strong current systems and may generate non-planar contributions. (3) The generation of 'blizstatic', localised random electric fields caused by the spin drift of moving charged snow and ice particles that produce significant noise in the electric fields during periods of strong winds. At wind speeds above $\sim 10 \mathrm{~m} \mathrm{~s}^{-1}$, the effect of the distortion created by the moving snow is broad-band. Station occupation times need to be of sufficient length to ensure data are collected when wind speed is low. (4) Working on glaciated terrain introduces additional safety challenges, e.g., weather, crevasse hazards, etc. Inclusion of a mountaineer in the team, both during the site location planning and onsite operations, allows these hazards to be properly managed. Examples spanning studies covering development and application of novel electromagnetic approaches for the polar regions as well as results from studies addressing a variety of differing geologic questions are presented. Electromagnetic studies focusing on near-surface hydrologic systems, glacial and ice sheet dynamics, as well as large-scale volcanic and tectonic problems are discussed providing an overview of the use of electromagnetic methods to investigate fundamental questions in solid earth studies that have both been completed and are currently ongoing in polar regions.
\end{abstract}

Graham J. Hill

gjhill@ig.cas.cz

Extended author information available on the last page of the article 
Keywords Electromagnetic methods $\cdot$ Magnetotellurics $\cdot$ Polar regions · Antarctica Arctic $\cdot$ Source field $\cdot$ Instrumentation $\cdot$ Tectonics $\cdot$ Magmatism $\cdot$ Glaciology

\section{Introduction}

The Arctic and Antarctic Circles at $66.56^{\circ}$ mark the lowest latitude that experiences $24 \mathrm{~h}$ of continuous day (Sun above the horizon) and night (Sun below the horizon) at least once per year. The polar regions, those that surround the geographical North and South Poles, are more typically defined as the latitudes above $60^{\circ}$, with Antarctica defined by the 1959 Antarctic treaty as all lands and ice shelves south of $60^{\circ} \mathrm{S}$ latitude. For the purpose of this review, polar regions can be divided into two categories. Those at high latitude with persistent (year-round) thick snow and ice cover (i.e. ice sheets rather than smaller scale local alpine glaciers) are 'cold polar regions', and those at high latitude without year-round snow and ice cover are 'warm polar regions'. In this review, the unique challenges associated with working in these regions are discussed, all of which are relevant to the cold polar regions, while only a subset are relevant to the warm polar regions as the unique challenges associated with working in the snow and ice cover are typically avoided by completing data collection during periods free of seasonal snow cover.

The polar regions provide the opportunity to investigate fundamental questions in Earth studies ranging from climate change and its impact (e.g., Maclennan and Lovell 2002; Naish and Zwartz 2012; Golledge et al. 2015; Levy et al. 2016), to tectonic processes both active and extinct (e.g., Kyle et al. 1992; Storey 1996; Storey et al. 1999; Fitzgerald 2002; Al-Kindi et al. 2003; Zandt et al. 2004; Vaughan and Storey 2007; Goodge et al. 2012; Bezada et al. 2014; Brenn et al. 2017; Shen et al. 2017; Wannamaker et al. 2017). The two regions where active ice sheets can be found and hence fit the definition of a cold polar region-those that maintain year-round thick snow and ice cover-are the Antarctic Continent and Greenland. Additionally, the much smaller ice caps which have an area less than $50,000 \mathrm{~km}^{2}$ and include: the Barnes ice cap $6000 \mathrm{~km}^{2}$ (a remnant of the Laurentide ice sheet which retreated 16,000 years ago) on Baffin Island Canada; the Scandinavian West Svartisen ice cap $201 \mathrm{~km}^{2}$; the Karpinksky ice cap $2800 \mathrm{~km}^{2}$ on October Revolution Island Russia; and Vatnajokull ice cap Iceland $7700 \mathrm{~km}^{2}$ (Europe's largest) are cold polar regions. However, there has been no known electromagnetic surveying on the ice caps. Both Antarctica and Greenland (Fig. 1) are comparatively poorly understood in a global perspective, including how these large land masses fit lithospheric plate reconstructions (Lawver et al. 1998; Dalziel and Lawver 2001). Further understanding of these regions has implications for global tectonics and how these are linked to climate trends (Maclennan and Lovell 2002). A complete loss of the Greenland ice sheet would result in $7 \mathrm{~m}$ of sea-level rise (Dowdeswell 2006), while melting of the Antarctic glaciers and ice sheets would cause large sea-level rises of $\sim 0.24 \mathrm{~m}$ from the glaciers of the Antarctic Peninsula (Pritchard and Vaughan 2007), 3.2 $\mathrm{m}$ for the West Antarctic Ice Sheet (Bamber et al. 2009; Joughin and Alley 2011), and $60 \mathrm{~m}$ for the East Antarctic Ice Sheet (Ivins 2009; Willis and Church 2012).

Electromagnetics (EM), and in particular magnetotellurics (MT) with its wide bandwidth, is ideally suited for addressing fundamental problems in solid Earth studies over broad depth scales (e.g., Booker et al. 2004; Unsworth et al. 2005; Wannamaker et al. 2009; Heise et al. 2012; Hill et al. 2015; Bedrosian et al. 2018). Thick snow and ice cover the majority of the surface in polar environs for at least a portion of the year; $98 \%$ of the 

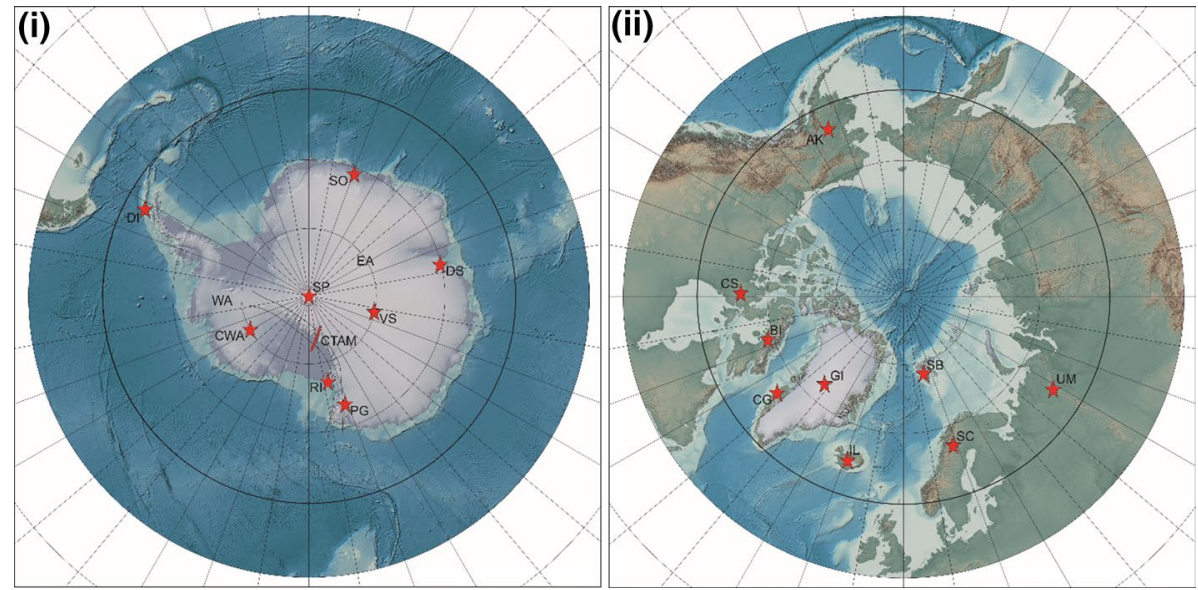

Fig. 1 The polar regions are defined as those above $60^{\circ}$ latitude (drawn bold). $\mathbf{i}$ In the Southern hemisphere that is the Antarctic Continent which is covered by a permanent thick layer of snow and ice. EM studies while still rare are becoming more common and have been completed at: Central West Antarctica (CWA); South Pole (SP); Schirmacher Oasis (SO); Vesford Hills and Davis Station (DS); Central Transantarctic Mountains (CTAM); Mount Erebus and Ross Island, and the Dry Valleys (RI); Vostok Station (VS); Priestly Glacier (PG); and Deception Island (DI). ii The Northern Hemisphere has both regions that are covered in thick snow and ice year round and those that are snow free during the northern summer, with MT studies having been undertaken in both settings at: Alaska (AK); the northern Canadian Shield (CS); Baffin Island (BI); Coastal Greenland (CG); the Greenland Icesheet (GI); Iceland (IL); Svalbard (SB); Scandinavia (SC); and the Ural Mountains (UM)

Antarctic continent is ice-covered with an average ice thickness of $1.9 \mathrm{~km}$ (Ivins 2009; Willis and Church 2012), while the Greenland Ice Sheet covers $80 \%$ of the surface with an average thickness of $2.1 \mathrm{~km}$ (Dowdeswell 2006). The presence of these large ice sheets necessitates geophysical methods to investigate the processes occurring beneath the snow and ice coverage. The thick ice coverage of both the Antarctic continent and Greenland effectively means what would typically be the working surface (air/earth interface) is at a depth of $\sim 2 \mathrm{~km}$. The thick ice coverage does have the advantage of effectively upward continuing the MT response, suppressing static distortion. As such, MT is the most appropriate tool for all but those studies investigating the dynamics of the overlying ice sheets and glacial flow. The minimal ground disturbance and environmental impact, together with manageable logistical support requirements, make MT, with its sensitivity to the thermal structure and the presence of fluids, an increasingly important method in polar regions.

The lack of vegetation and local cultural noise make polar regions an excellent target for obtaining high-quality EM/MT data; however, there are several challenges that need to be overcome in order to do so. (1) High contact resistances are encountered, with values to $10 \mathrm{M} \Omega$ reported (Hessler and Jacobs 1966) between electrodes and the surficial snow (firn-multiyear partially compacted snow) and ice cover, or zones of permafrost. Contact resistance acts as a source impedance in series with the signal voltage and creates voltage dividers with any shunt impedances that exist between the receiver's input and its grounding reference (e.g., Zonge and Hughes 1985; Ingeman-Nielsen 2006; Stodt pers comm. 2018). (2) The proximity to the geomagnetic poles raises the possibility of time segments during measurement where the source field is non-planar (e.g., Pirjola 1992; Pirjola and Viljanen 1998; Vilajnen et al. 1999). (3) Non-anthropogenic local noise sources such as the generation of 'blizstatic', localised random electric fields resulting from the spin drift 
of moving charged snow and ice particles (e.g., Savelyev et al. 2006; Gordon and Taylor 2009), can be problematic. (4) Working in these extreme climate zones and glaciated terrain introduces additional logistical and safety challenges, e.g., fast moving severe weather systems and crevasse hazards.

Some of these challenges are not unique to polar regions. For example, the issue of very high contact resistance between electrodes and surface materials also occurs in arid sandy desert environs, in glacial and high-altitude snow caps in the mid-latitudes, as well as in regions with significant permafrost coverage which may be found in areas of either high elevation or high latitude. Non-planar source effects may be encountered in a narrow $\left( \pm 3^{\circ}\right)$ corridor either side of the magnetic equator as a result of the equatorial electro-jet. When travel is required over any glaciated terrain (e.g., low latitude alpine glaciers or high elevation snow fields), one must be aware of the associated potential hazards (e.g., crevasse fall, ice falls, and avalanche). Consideration of source effects is required when working in highlatitude warm polar regions, in the northern hemisphere (Fig. 1) locations such as Alaska (e.g., Fisher et al. 2004; Glen et al. 2007), northern Canada (e.g., Jones and Spratt 2002; Evans et al. 2005; Spratt et al. 2014), Scandinavia (e.g., Korja et al. 2002; Lahti et al. 2005; Sokolova et al. 2007; Cherevatova et al. 2015a), Svalbard (e.g., Beka et al. 2015, 2016, 2017a, b), coastal Greenland (e.g., Heincke et al. 2015; Hautot and Tarits 2016; Lauritsen et al. 2016), Russia (e.g., Bubnov et al. 2007), and in the southern hemisphere (Fig. 1) for those working in the sub-Antarctic islands (e.g., Pedrera et al. 2012) where during the summer months the ground is not covered in snow and ice as there is the potential for periods where the source field is a non-plane wave. However, the 'cold polar regions' are commonly the only locations where all of these challenges are encountered together.

The first telluric observations made on a polar ice cap were done by Hessler and Jacobs (1966) at the then Soviet (now Russian) Vostok station in Central East Antarctica (Fig. 1). Their telluric measurement suggested that MT studies were possible in the cold polar regions, whereas prior to this it had been assumed that the high contact resistance would preclude the accurate measurement of the telluric response. MT measurements were first undertaken and reported qualitatively as part of the Dome C geophysical study (Bentley et al. 1979; Shabtaie et al. 1980), followed by work local to Scott Base on Ross Island (Boteler and Willink 1984). The first quantitative presentation of MT results consisted of four measurements on Priestly Glacier in North Victoria Land (Beblo and Liebig 1990). The first presentation of a resistivity section was a forward model in Central West Antarctica based on a 10-site survey (Wannamaker et al. 1996). Surveys of similar scale were completed at South Pole (Wannamaker et al. 2004), Schirmacher Oasis East Antarcticathough, this work was completed with measurements made in exposed earth rather than in permanent snow/ice cover (Murthy et al. 2013), and Vestfold Hills East Antarctica (Peacock and Selway 2016). A long-running single station was deployed at Vernadsky station on the Antarctic Peninsula to investigate the effect of the auroral electro-jet over a longer time scale (Korepanov et al. 2006). More recent work on a larger scale has been undertaken. Wannamaker et al. (2017) studied the tectonics of high rift shoulders using a $550 \mathrm{~km}$ MT transect across the central Transantarctic Mountains. Hill et al. (2019) have collected the first truly 3D data set, 129 stations over Ross Island; a 3D interpretation is currently underway by these investigators to elucidate the structure of the Mount Erebus system and its relation to the Terror Rift. This work will provide insight into the tectonic and magmatic processes responsible for the observed alkalic and ultra-alkalic volcanism there, which can be applied to similar systems globally. The first work on the Greenland Ice Sheet has recently been undertaken (Selway and Conrad 2018; Ritter and Kuleassa, pers. comm. 2018) to investigate the role and influence of the Iceland mantle plume on current 
tectonics of Greenland and stability and dynamics of the Greenland Ice Sheet (Fig. 1). Future potential exists for studies of ice sheet and glacial dynamics, and characterisation of subglacial hydrologic systems (Key and Siegfried 2017; Siegert et al. 2018); however, the applicability and success of these studies may be hampered by the challenges of acquiring high-quality electric field data at the required periods without the inclusion of active source methods.

There has been little use of grounded controlled-source Electrical and EM methods in the ice-covered polar regions, largely due to the difficulty of injecting current into the firn and ice. The first controlled-source experiments conducted in the polar regions were direct current (DC) resistivity measurements to study ice sheet properties (Hochstein 1967), initially on the Greenland Ice Sheet in 1959, and then in Antarctica at Roosevelt Island and the Ross Ice Shelf in 1961-63. Further DC resistivity work has been completed on the Ross Ice Shelf (Bentley 1977), on the Antarctic Peninsula (Reynolds and Paren 1984), and at then Ice Stream B now Whillans Ice Stream (Shabtaie and Bentley 1994). The DC resistivity efforts were followed by higher-resolution frequency domain electromagnetic (FDEM) surveys, used to identify conductive bodies attributed to saline brines underlying the relatively thin $(650 \mathrm{~m}$ ) ice sheet of western Dronning Maud Land (Ruotoistenmäki and Lehtimäki 1997). More recently, an airborne time-domain electromagnetic (TEM) survey was conducted in the McMurdo Dry Valleys (Dugan et al. 2015; Mikucki et al. 2015; Foley et al. 2016). The Dry Valleys are a series of valleys in Victoria Land that are protected from glacial flow and cover by the surrounding mountains. The ice-free setting of the Dry Valleys makes them a unique study location suited to the shallow resolving ability of airborne controlled-source methods, which identified a laterally extensive groundwater system. Ground (Ice) Penetrating Radar (GPR) has become commonly used to investigate and characterise dynamics of ice sheets, including their internal stratigraphy and strain history, as well as their response to climatic and subglacial forcings in both Greenland and Antarctica (e.g., Whillans 1976; Siegert 1999; Fahnestock et al. 2001; Macgregor et al. 2015; Jordan et al. 2018a, b). GPR is also an important operational tool used to identify crevassefree travel routes for large tracked vehicles, to identify stable road paths for transition zones between ice shelf and terra firma, and in the location of buried infrastructure ranging from fuel caches to instrumentation (Briggs et al. 2016; Campbell et al. 2018). The unique setting of the Dry Valleys and extensive use of GPR as both a research and operational tool demonstrate the effectiveness of controlled-source EM studies (as the groundwater system had previously not been identified by numerous other geophysical studies) in high latitudes while reinforcing the limited application of these methods in the ice-covered polar regions given the limited depth of investigation they provide. Obviously there are countless additional studies that for space purposes have not been mentioned in this brief overview of the use of EM in polar regions, which serves to identify key early works and representative examples of current usage.

\section{Source Fields}

MT studies require the fundamental assumption that the magnetic source field is a vertically propagating horizontally polarised plane wave. In both warm and cold polar regions, the coming together of the solar wind-generated magnetospheric currents towards the Earth's magnetic poles during increased activity levels will cause both the strength and size of influence of the polar electro-jet (Fig. 2) to increase (Olsen 2007; Constable 2016; 


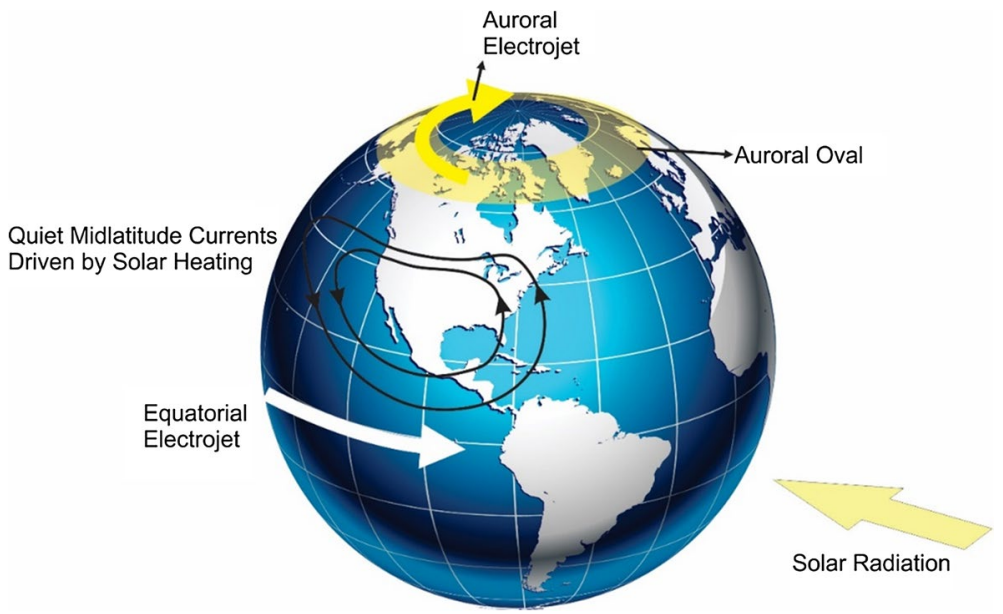

Fig. 2 The different components of the Earth's magnetic field zones. The high energy auroral and equatorial zones are shown with their approximate areas of influence. The auroral zone characterised by the auroral oval extends between $\sim 65-80^{\circ}$, while the eastward flowing equatorial electro-jet is typically constrained to a narrow band $\left( \pm 3^{\circ}\right)$ surrounding the dip equator. The mid-latitudes are less energetic with ionospheric current largely resulting from the solar quiet day variation (Sq). Definitions and regions after Akasofu (2015)

Olsen and Stolle 2017), which may challenge the validity of the plane wave assumption (e.g., Rostoker 1996; Pirjola 1992). There are two electro-jets: (1) the auroral, which when in an energetic state has a western direction of flow in both northern and southern hemisphere auroral ovals. The auroral oval is the zone containing large non-uniform time-varying ionospheric currents from approximately $60^{\circ}-80^{\circ}$ latitude (north and south); (2) the eastern propagating equatorial, which are the electric currents that propagate within the Kennelly-Heaviside region (the layer of ionised gas $~ 90-150 \mathrm{~km}$ above the surface) of the Earth's ionosphere. The equatorial electro-jet is a result of the global solar wind-generated solar quiet (Sq) and occurs in much narrower band $\pm 3^{\circ}$ of the magnetic equator creating a magnetic field that is significantly stronger than that of the adjacent Sq zones. The validity of the plane wave assumption may be challenged at both equatorial and high latitudes creating distortion of the MT response when localised ionospheric currents are in a high energy state.

The polar electro-jet has two components. The first, known as the convection electrojets, is produced by a persistent current system creating small variation quasi-stationary electro-jets originating on the diurnal side of the planet and running both east and west towards the auroral zone midnight. The second are the substorm-generated electro-jets (Fig. 3). The polar electro-jet becomes more active in the presence of the short duration (typically $\sim 1 \mathrm{~h}$ or less) magnetospheric (or auroral) substorms which are generated by the sudden release of energy from the magnetospheric tail that is injected into the ionosphere at high latitudes. Substorms are relatively infrequent during the solar cycle minimums; however, during the solar cycle maximum substorms become more frequent and a cycle can develop where new substorms begin prior to the completion of the preceding substorm (Akasofu 1964; Potemra 1991). This 'substorm train' creates an extended period with increased current flow, during which the validity of the plane wave assumption is challenged. This is compounded by oscillations in the location of the polar electro-jet as it migrates during the progression of the substorm. A complicated magnetic field structure is 

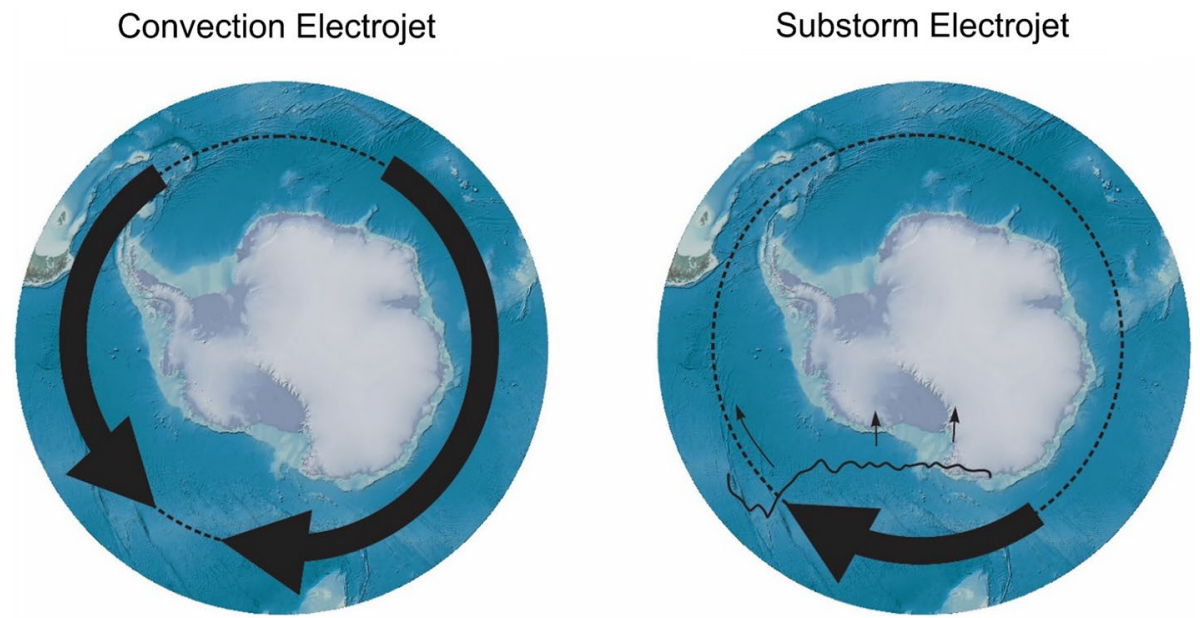

Fig. 3 Auroral electro-jets include both the convection and substorm electro-jet. The convection electrojets result from a two-cell convection pattern that forms as the ionosphere plasma flows across the polar from noon to midnight and returns to the dayside via paths on the dawn and dusk sides at lower latitude. In contrast, the substorm electro-jet flows in the midnight sector and forms in response to the formation of a substorm (current) which occur as a result of a massive charged particle influx to the ionosphere from a 'collapse' of the magnetosphere tail. Modified from Baumjohann and Treumann (1997)

created during this process in which it is difficult to separate the contribution to the magnetic field by traditional MT sources from that of the polar electro-jet. Broadly speaking, there are two approaches to account for the electro-jet-induced non-plane wave magnetic field effects: (1) modelling and removal of the magnetic field component produced by the electro-jet (e.g., Pirjola 1992; Viljanen et al. 1993, 1999; Pirjola and Viljanen 1998); (2) to identify periods where the polar electro-jet is in a low energy state and non-plane wave effects are minimal (e.g., Viljanen 1996; Garcia et al. 1997; Jones and Spratt 2002) and comparison of low and high energy time responses to give an estimate of the potential existence and severity of non-plane wave effects (Wannamaker et al. 2004, 2017; Hill et al. 2019).

A simple model of a stationary electro-jet and its effect on a conductivity model were used to demonstrate that the electro-jet for periods shorter than $900 \mathrm{~s}$ does not introduce a significant distortion in the recovered conductivity structure (Osipova et al. 1989). More realistic (complex) representations of the electro-jet have been used in efforts to minimise or remove the distortion of the MT response due to source effects, with varying degrees of success. Rather than identifying periods when the non-plane wave effects are present, Viljanen et al. (2004) investigated the ability to average out the distortion over many events. Both a 3D model of the electro-jet coupled with a 1D Earth and a line current electrojet with a more complex 2D Earth were used, and showed that the averaging approach does reduce the distortion but does not eliminate it adequately to provide undistorted MT responses in the auroral zone. Further, Pirjola (1992) demonstrated that representing the electro-jet as a simplified infinite line current can drastically underestimate the introduction of non-plane wave source effects and consequently produces MT responses that may be highly distorted in comparison to the more realistic 3D electro-jet models. The general 3D formulation of ionospheric magnetosphere currents was determined by Hakkinen and Pirjola (1986) for the exact response at the Earth's surface of a simple layered 
Earth. However, these relationships are characterised by complicated inverse Fourier transforms that are numerically expensive to compute. These studies using more realistic models of the electro-jet suggest that the distortions associated with the plane wave assumption become noticeable for periods greater than $\sim 60 \mathrm{~s}$ (Hakkinen and Pirjola 1986; Pirjola 1992; Viljanen et al. 1993). Given the early appearance of distortion ( $60 \mathrm{~s})$ in the MT response, a significant effort has been made to simplify and speed up the calculation of the surface fields. These include treating the contribution from either a half space or layered Earth model as an image (complex image method) of the primary ionospheric source (Boteler and Pirjola 1998; Pirjola and Viljanen 1998; Viljanen et al. 1999; Engels et al. 2002), which produces a more efficient numerical formulation of the surface electromagnetic field. While it has been shown that in general the source effect is inversely proportional to the distance from the centre of the ionospheric current system, however, it is also dependent on the Earth's conductivity structure with conductivity being inversely proportional to source effects. These models of the source field and how to remove distortion from the MT response are all based on simple Earth models. The effect of complex small-scale variability of the shallow resistivity structure (i.e. local 3D resistivity structures representative of actual geology) on the electric field is a topic for further work-at high frequencies the local geology could have a greater effect than a complicated non-planar source field (Viljanen et al. 1999). What all of these different approaches to determining the distortion of the source field have in common is that changes in model parameters can greatly affect the resultant distortion, and as such an accurate model of the ionospheric current system at the time of measurement is required to recover undistorted MT responses.

Given the complexity involved in recovering an undistorted response in the presence of strong source effects, workers in polar regions have more practically identified time segments when the source field adheres to the plane wave assumption and only use these time windows to estimate the magnetotelluric response. When the plane wave assumption is honoured, spatial variation in the vertical magnetic field response is an indication of spatial heterogeneity of the resistivity structure (Parkinson 1962). However, in polar regions temporal variations in the vertical magnetic field response may result from non-plane wave source field components at longer periods and these time-series segments need to be identified and rejected during the signal processing (Mareschal 1986; Garcia et al. 1997; Pirjola and Viljanen 1998; Jones and Spratt 2002; Wannamaker et al. 2004; Peacock and Selway 2016). Jones and Spratt (2002) demonstrate that given a 1D Earth locally (i.e. near zero induction vectors), the identification and removal of outliers in the vertical magnetic field resulting from non-plane wave sources effectively remove distortion from the magnetotelluric response. They computed two sets of responses, one which included all of the time series while the second sorted out periods where the solar activity was above a threshold value ( $30 \%$ of the time series was removed). The sorting was completed using the formulation $1.5 \times \sigma \leq B_{z}(\omega, t) / \sqrt{ }\left[B_{x}(\omega, t)^{2}+B_{y}(\omega, t)^{2}\right]$ where $\sigma$ is the standard deviation of the vertical magnetic field, $B_{n}$ the respective short-term amplitudes of the frequency domain magnetic field components, and $\omega$ is angular frequency. When this relationship is true, the source is deemed to be non-planar. These two sets of responses produced different resistivity models; consistent models of the subsurface required rejection of data contaminated by source field effects.

The sorting described by Jones and Spratt (2002) using the above formulation is effective for zones where horizontal induction currents are small, i.e. that lateral heterogeneity is not present in the electrical structure of the survey area and the distortion-free induction vectors are small. Wannamaker et al. (2004) could not assume that all observed high vertical magnetic field values were the result of non-plane wave source effects rather than 
lateral heterogeneity being present within the subsurface electrical structure of the survey area. Their approach to remove outliers was a variant of robust processing employing a jackknife methodology (Chave and Thompson 1989; Thompson and Chave 1991), in which an emphasis was placed on rejecting data segments producing outliers in the vertical magnetic field response. Identification of outliers in individual components of the MT response (i.e. vertical magnetic field transfer functions) can be used as a proxy (Wannamaker et al. 2004) to guide removal of time segments where outliers are present in the other components of the MT response (i.e. the transfer functions between the horizontal electric and magnetic fields). The need to identify outliers in the vertical magnetic field response was a result of the difficulty in obtaining good estimates of the impedance due to the wind-blown snow introducing noise (discussed as follows) much of the time (Wannamaker et al. 2004). Outlier removal directly from the impedance should be feasible in quieter environments free of such significant external local noise sources.

A series of papers discussing the Baltic Electromagnetic Array Research-BEAR (e.g., Korja et al. 2002; Varentsov et al. 2002, 2003a, b; Lahti et al. 2005; Sokolova et al. 2007) and Magnetotellurics in the Scandes-MaSca (e.g., Cherevatova et al. 2015a, b) experiments in Fennoscandia concluded that non-planar source field distortion either was not present or effectively removed for periods less than $\sim 10,000 \mathrm{~s}$. Time-series data were independently processed using three different robust remote reference techniques (Egbert 1997; Smirnov 2003; Varentsov et al. 2003a) for the BEAR experiment. The impedance response for all components of the amplitude and phase had little scatter when results from the differing processing schemes were compared to periods of 10,000 s (Lahti et al. 2005), from which it was interpreted that the distortion attributable to a non-planar source in the MT response is suppressed. The long measurement time allows determination of an effective source (averaged over time) with a non-planar source distortion much less than that of a simple line current (Varentsov et al. 2003b). Results from the three different processing schemes were averaged to produce the final MT response estimates. The more recent multivariate principal component approach of Smirnov and Egbert (2012) was also used to determine that MT responses free of source field-induced distortion were obtained for the MaSca experiment (Cherevatova et al. 2015a). A similar approach was used in a series of papers exploring Svalbard (Beka et al. 2015, 2016, 2017a, b) to infer high-quality data free of source field-generated distortion were obtained (Smirnov, pers. comm. 2019).

Peacock and Selway (2016) introduced additional constraints to assist in the identification of times when source field effects are present. They exploited the assumption that the apparent resistivity is time invariant (Banks 1998); when the apparent resistivity was not time invariant, they inferred source field effects are present and the time segment is rejected. This is valid for all but a few unique geologic settings, e.g., an active magmatic system in an eruptive phase where the partial melt fraction of the system is varying with time. They used the formulation $\rho_{a}^{i j}(\omega, t)=\left|Z_{i j}(\omega, t)\right|^{2} / \mu_{o} \omega$ where $\rho_{a}$ is the apparent resistivity, $\mu_{o}$ is the magnetic permeability of free space (note this was mis-defined in the original paper as magnetic susceptibility), and $i$ and $j$ are components of the measured horizontal and electric fields, respectively, to estimate the apparent resistivity. If the apparent resistivity varied by more than two standard deviations for a given time window, source field effects were deemed to be present and the time window was removed from the transfer function determination. As an additional check on the complexity of the source field, a principal component analysis can be carried out on the measured magnetic fields; for a planar source field absent of significant other noise, only two principal components should be present (Egbert 2002). As such, when the condition of other noise sources being absent is met the presence of more than two principal components is indicative of a non-planar 
source field. When a third principal component was identified to exist within a standard deviation of the first two principal components, source field effects are likely present and the time window should not be included in determination of the MT transfer functions (Peacock and Selway 2016). These criteria are considered to identify 'good' time windows for determining the transfer functions (Fig. 4) and how the inclusion of time windows with reduced data quality affects the MT response. Additionally, time windows with wind speed above 15 knots (Fig. 4) were removed from the estimation of the final transfer functions. The removal of the time windows associated with increased wind speeds is the most probable cause for the improvement in the transfer functions as the non-planar source effects are largely avoided at the periods of interest in MT studies.

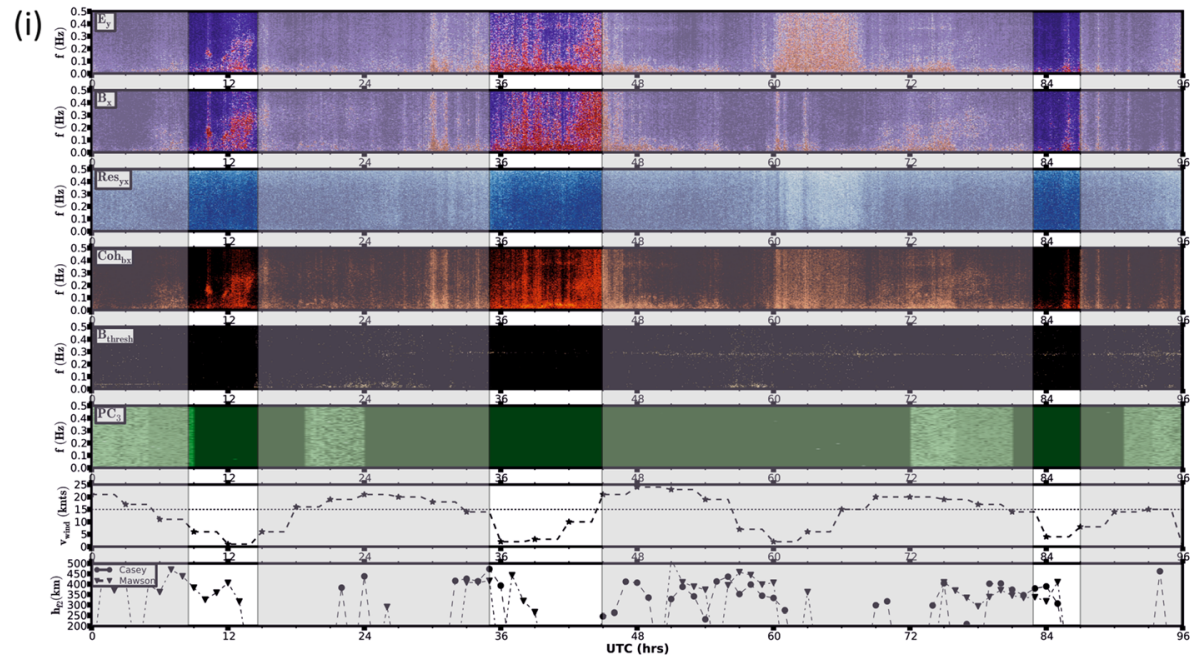

(ii)
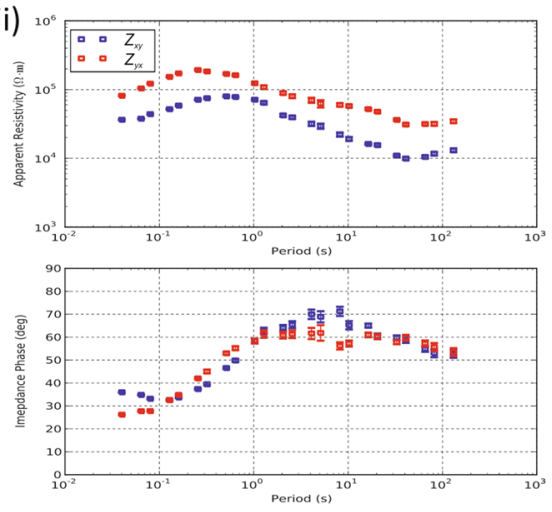
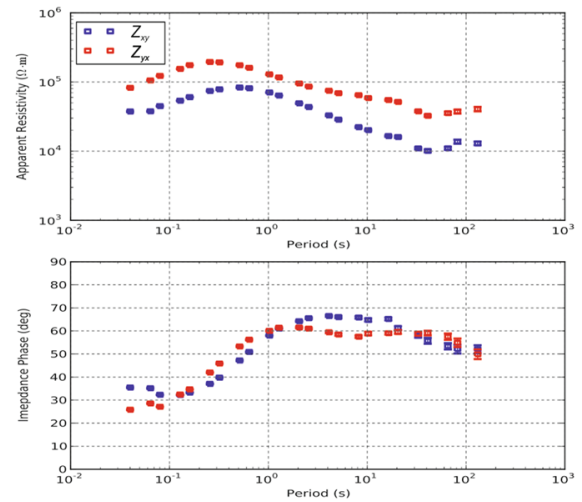

Fig. 4 i Identification of good time windows to estimate the MT transfer function by estimating covariant parameters (Peacock and Selway 2016). Warm colours and whites represent high values. From top to bottom plotted are the spectrograms for $E y$ and $B x$, the apparent resistivity, coherence, threshold of $B z$, the third principal component of the magnetic fields, ground wind speed, and height of the $F 2$ layer. ii Resultant MT transfer function estimations when all data are included (left) and when time windows that may be affected by source field effects and wind noise are removed (right). Modified from Peacock and Selway (2016) 
The recent work of Wannamaker et al. (2017) in which data collection was completed during the solar minimum defines three tests to determine the potential severity and rule out influence of non-plane wave source effects. First, the magnetic activity indices (Zhizhin et al. 2008) were evaluated for the duration of the two field seasons with the highest activity level reached being 'Unsettled' for 2 days during the first season and a single day during the second field season with the solar activity level classified as 'Quiet' for all but those 3 days. This reflects the lack of strong current systems being present in the polar electro-jet, which can lead to non-planar source effects during the data collection. Next, the signal spectral strength was analysed as a function of time for each measurement in which a diurnal variability in the ionospheric signal strength was identified. The diurnal variation is characterised by $\sim 12$-h periods of increased energy beginning early afternoon Greenwich Mean Time (GMT), and is most noticeable in the horizontal magnetic components (Fig. 5). This oscillation in the signal strength is attributed to the polar electro-jet solar quiet variation (Akasofu 1977), with the high energy periods resulting from the closer approach of the auroral oval limb with the concentrated field-aligned ionospheric current flow. The constancy of the cyclic behaviour of the signal level is an indication that there was minimal solar magnetic disturbances during the observation period. Finally, an analysis of this signal behaviour was completed to determine whether the diurnal variations contain a contribution from non-plane wave sources. This was done by subdividing the total recording into alternating 12-h windows containing the high and low activity segments, respectively. Each group was then remote reference processed using robust outlier removal (Jones et al. 1989) to produce two independent responses representing the high and low activity levels (Fig. 5), which were used to provide an estimate of the severity of any nonplane wave effects. The response from each of these two data subsets was equal apart from minor scatter over the entire period range, indicating that the source effects were negligible on the MT responses, and final responses were calculated incorporating the entire time series (excluding time segments of local wind-induced noise). The ongoing work by Hill et al. (2019) employs a similar approach to argue that source field effects have been either avoided or removed.

\section{Instrumentation and High Impedance Effects}

In a magnetotelluric sounding, the surface electric field measurements are made by measuring the potential difference between two grounded electrodes that make up the bipole. In most terrestrial settings, the contact resistance is modest $(<\sim 10 \mathrm{k} \Omega)$ and for typical connecting wire lengths to a receiver $(\sim 100 \mathrm{~m})$ the adverse effects of interaction of the contact resistance with the parasitic distributed wire-ground capacitance (Zonge and Hughes 1985) occur at frequencies above those of interest for MT. However, in settings with very high contact resistances (e.g., thick snow and ice cover, arid sandy desserts) the frequency at which the resulting distortion becomes significant is shifted into the typical period band of interest in MT. The approach that has typically been taken for completing MT soundings on polar ice caps has been to adapt commercially available systems to account for the very high contact resistance observed at the electrode interface via custom buffer amplifiers (Wannamaker et al. 1996, 2004, 2017; Peacock and Selway 2016; Hill et al. 2019).

The measured input voltage can be described by the following relationship using the nomenclature of Wannamaker et al. (2017) as $V_{\text {in }} / V=Z_{\mathrm{sh}} /\left(Z_{\mathrm{s}}+Z_{\mathrm{sh}}\right)$ where $V_{\text {in }}$ is the voltage observed at the first amplifier's input (typically in the receiver) and $V$ is the desired 
(i)

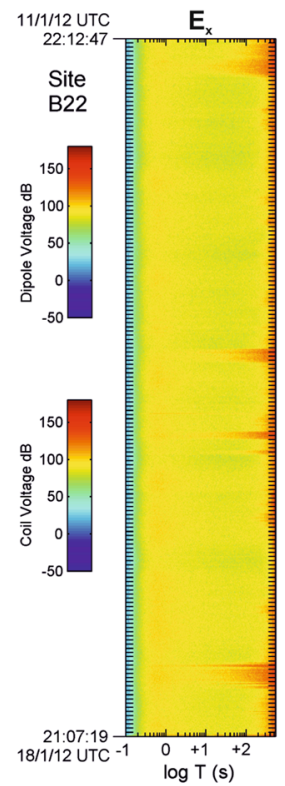

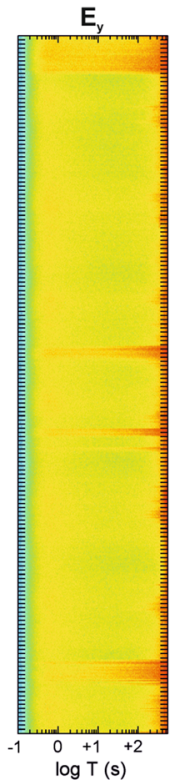
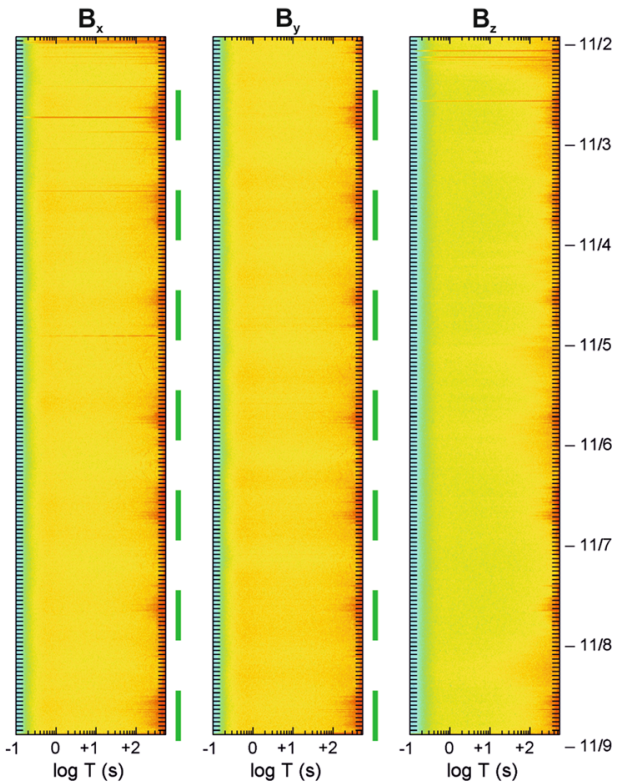

(ii)
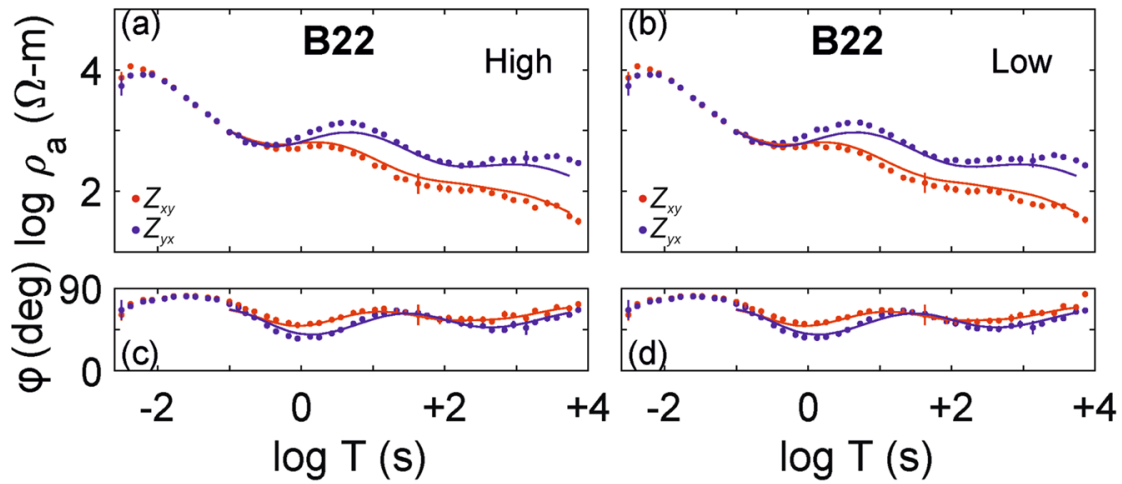

Fig. 5 i Spectrograms showing the energy level observed in each channel. A diurnal high and low energy period can be identified (most easily seen in the horizontal magnetic components) with the high energy segments centred on local midnight identified by green bars. ii Sounding curves computed from subsets of the high and low activity times of the diurnal signal variation. The response curves from each subset show only minor variation indicating that non-planar source effects are largely removed or avoided. Reproduced from Wannamaker et al. (2017)

voltage. Here, $Z_{\mathrm{sh}}$ is the shunt impedance acting at the amplifier's input and $Z_{\mathrm{s}}$ is the series impedance including the contact resistance at the electrode interface. In a terrestrial setting using a receiver designed for MT work, the normal case is $Z_{\mathrm{sh}} \gg Z_{\mathrm{s}}$ such that $V_{\text {in }} \approx V$ at frequencies of interest for MT. This is not the case for polar regions where the contact resistance between the electrode and firn/ice or permafrost interface is large $(\sim 1 \mathrm{M} \Omega$, often greater) and long bipoles (150-300 m) are sometimes used (e.g., Wannamaker et al. 2017; Hill et al. 2019). These conditions can lead to voltage divider interactions between the contact resistance and capacitance of the wire that result in phase shifts and attenuation of the 
$E$-field voltage at periods of interest in MT, a fuller discussion of contact interactions can be found in Wannamaker et al. (2004, 2017). Using buffer amplifiers at the active electrodes to isolate the high contact resistance can overcome these issues (Stodt 2005) and an increase to the useful bandwidth of the system of approximately two orders of magnitude can be achieved where voltage divider effects are small.

The first successful telluric observations were made by Hessler and Jacobs (1966) at Vostok station where the observed electrode contact resistances in the snow/firn were $>10 \mathrm{M} \Omega$, although they did not employ buffer amplifiers. An Arrhenius dependency (the temperature dependence of reaction rates) exists for the snow/firn resistivity (Shabtaie and Bentley 1995) corresponding to a factor of 2 increase in resistivity for every $10{ }^{\circ} \mathrm{C}$ decrease in temperature. Work completed in Central West Antarctica was in a 'warm' region of the Antarctic continent with reported contact resistances of 0.4-0.5 M $\Omega$ which aided in minimising the data errors at short periods (Wannamaker et al. 1996). Subsequent studies at South Pole (Wannamaker et al. 2004), on the Polar Plateau (Wannamaker et al. 2017), and at Mount Erebus (Hill et al. 2019) were all at significantly colder regions of Antarctica $\left(\sim-30{ }^{\circ} \mathrm{C}\right)$ with higher contact resistances of up to $2 \mathrm{M} \Omega$ predicted. At South Pole and on the Polar Plateau, observed contact resistances of $0.75-1.5 \mathrm{M} \Omega$ were common (Wannamaker et al. 2004, 2017) with a trend towards lower contact resistances as the summer progressed which may in part be a result of surface warming into the austral summer. Erebus has a relief of $3794 \mathrm{~m}$, and measurements were completed from sea level to the summit plateau over a temperature band in excess of $40{ }^{\circ} \mathrm{C}$; again a general trend towards higher contact resistances at colder (higher altitude) locations was observed with the largest contact resistance $2 \mathrm{M} \Omega$ (Hill et al. 2019). The summit plateau was the exception to this general trend where the contact resistances observed where often under $0.5 \mathrm{M} \Omega$ even with these being the coldest conditions encountered. These low contact resistances likely result from a change in the chemical composition of the snow conditions created by the exsolution of magmatic gases from the summit lava lake and fumaroles.

Custom buffer amplifiers were first successfully deployed to isolate the high contact resistance from the receiver in Central West Antarctica by Wannamaker et al. (1996) where contact resistances of $0.5-0.6 \mathrm{M} \Omega$ were encountered. A full description of the first generation buffer amplifiers can be found in Wannamaker et al. (2004). A simpler updated version of these original buffer amplifiers (Numeric Resources LLC; Stodt 2005) has been used in recent work (Peacock and Selway 2016; Hill et al. 2019; Wannamaker et al. 2017). The current configuration (Fig. 6) is a non-inverting single-ended input design that is easily mated to commercial MT systems (e.g., Phoenix Geophysics V5-2000 system). Other important functional features include an input that has over-voltage protection, with a shunt resistance of $R_{\mathrm{sh}}=90.9 \mathrm{M} \Omega$ and a shunt capacitance $C_{\mathrm{sh}} \sim 20 \mathrm{pf}$, the output resistance is $\sim 50 \Omega$, and the output voltage is stabilised to drive a large capacitive load like that presented by a long cable (Stodt 2005). Field layout is similar to standard land operations using a '+' grounded bipole array (Fig. 6). Electrodes need to be electrochemically stable in the cold operating environment. Wannamaker et al. (1996, 2004, 2017) and Hill et al. (2019) used $45 \times 60 \mathrm{~cm}$ expanded CP Grade-2 titanium tubular slit sheets with brass hardware (Fig. 6) buried horizontally with bipoles varying from 150 to $300 \mathrm{~m}$, while Peacock and Selway (2016) used horizontally buried stainless steel plates as electrodes deployed in an ' $\mathrm{L}$ ' array. The bipole wire is not a single conducting wire as in land surveys, but rather a twisted pair shielded cable is used. Cable construction is important; twisted pair wires insulated with polyethylene have roughly half the parasitic inter-wire capacitance as the same with PVC insulation, and tolerate cold temperatures better. An overall PVC jacket is acceptable on small diameter cables, and 24 or 22 AWG conductors make bipole-length 


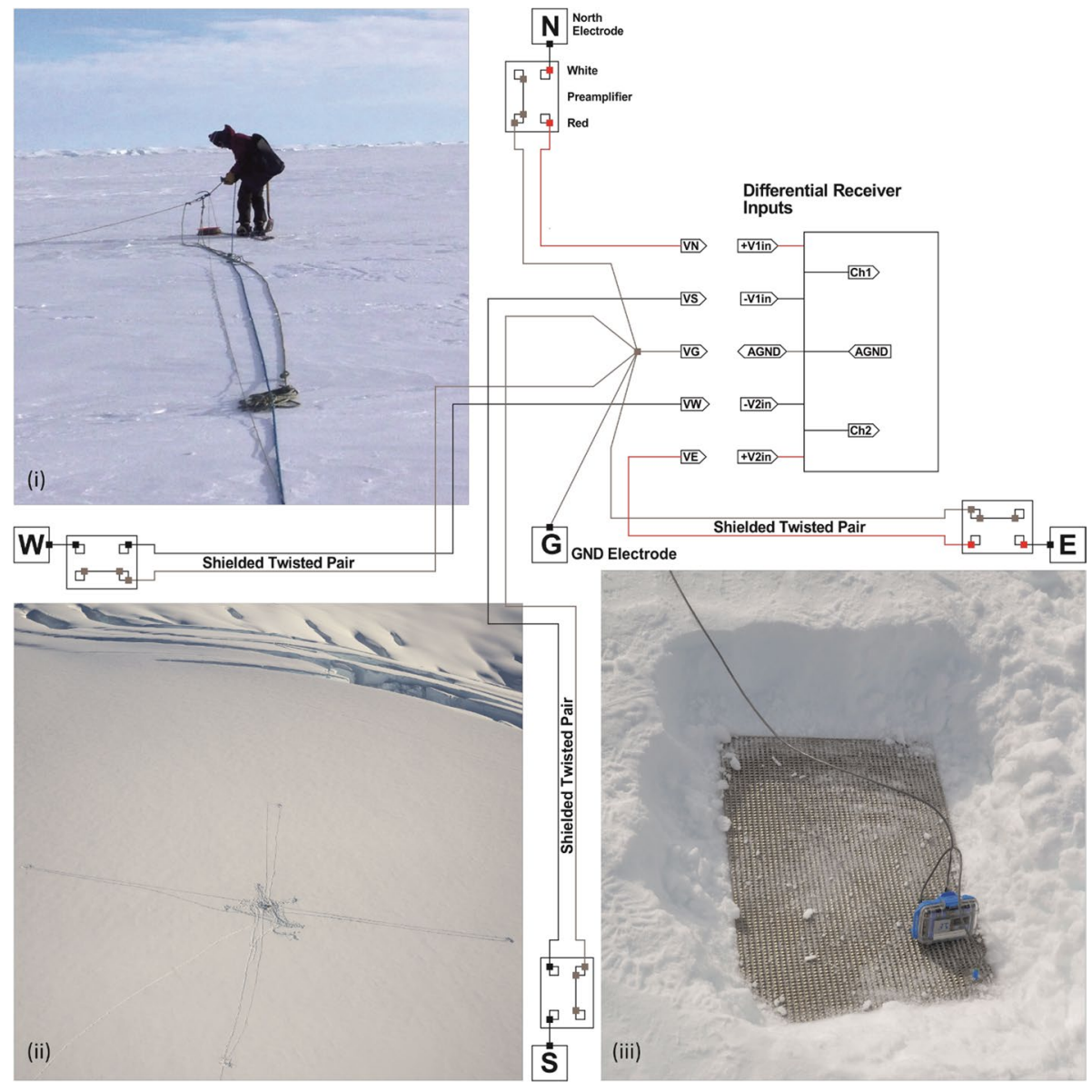

Fig. 6 Schematic sketch of MT site deployment using preamps for high contact resistance environments after Stodt (2005); i photograph of single-person rope travel on skis for electrode installation (photograph P. Bedrosian); ii aerial photograph of the installed site above a crevasse field on Mount Erebus (photograph D. Uhlmann); iii photograph of a titanium electrode connected to a preamp prior to burial (photograph K. Selway)

cables with manageable bulk and weight. The buffer amplifiers have a single-ended output (signal out and ground) that is connected to the matching receiver input terminal and to the receiver grounding reference via the twisted pair wires, and the shield drain wire connects to the receiver grounding reference at the receiver and is left unconnected at the buffer amplifier. A short $(\sim 50 \mathrm{~cm})$ connecting 'pigtail' of single conductor stranded wire is used between the electrode and the input of the buffer amplifier, adding $\sim 10 \mathrm{pf}$ to $C_{\mathrm{sh}}$. The buffer amplifiers are powered locally by AA batteries. For operation in cold polar regions, a battery chemistry of single-use lithium-iron-disulphide is preferred for the improved cold temperature operating performance compared to other chemistries, which for this design allows continuous operation for 10-14 days.

Recent work on the Greenland Ice Sheet (Selway and Conrad 2018; Ritter and Kuleassa, pers. comm. 2018) included a parallel test of the differing electrodes that have been recently used in these environments. MT measurements were carried out using equipment 
from the Geophysical Instrument Pool Potsdam. A long-period setup was completed spaced $\sim 14 \mathrm{~km}$ apart using fluxgate magnetometers and the expanded titanium metal sheet electrodes belonging to the University of Utah (Wannamaker et al. 2017), Marine Grade 316 stainless steel plates with 316 stainless steel connecting hardware belonging to the University of Adelaide (Boren, pers. comm. 2018) with observed contact resistance typically 1-2 M $\Omega$ (Selway pers comm. 2019). In addition, a broad-band configuration was tested using induction coils and wet cell porous pot silver-silver/chloride electrodes developed by the GFZ Potsdam group (Ritter, pers. comm. 2018). For the test glycerol, a non-toxic, non-ionic kosmotrope was added to the electrolyte ( $\mathrm{KCl}$ solution) to lower freezing point temperature. Preliminary processing of the data shows good agreement in the overlapping period bands of all measurements (Ritter, pers. comm. 2018). The titanium sheets and the stainless steel plates had good correlation over the periods of interest for MT measurements (Fig. 7), both the titanium and stainless steel electrodes record a diurnal signal, though the magnitude of the diurnal signal is larger in the stainless steel electrode. The titanium electrodes are $>99 \%$ pure titanium, while the stainless steel electrodes are an alloy. 316 stainless steel alloy contains $~ 16 \%$ chromium, 10\% nickel, and 2\% molybdenum, in addition to the standard steel alloy which is primarily iron and carbon; the chromium content creates the anti-corrosion property. Chromium contained in the stainless alloy reacts with the oxygen in the air to form a thin inert passive film of chromium oxide which prevents further oxygen diffusion to the steel that causes the corrosion reaction. The magnitude of the observed diurnal signal could represent a thermal effect related

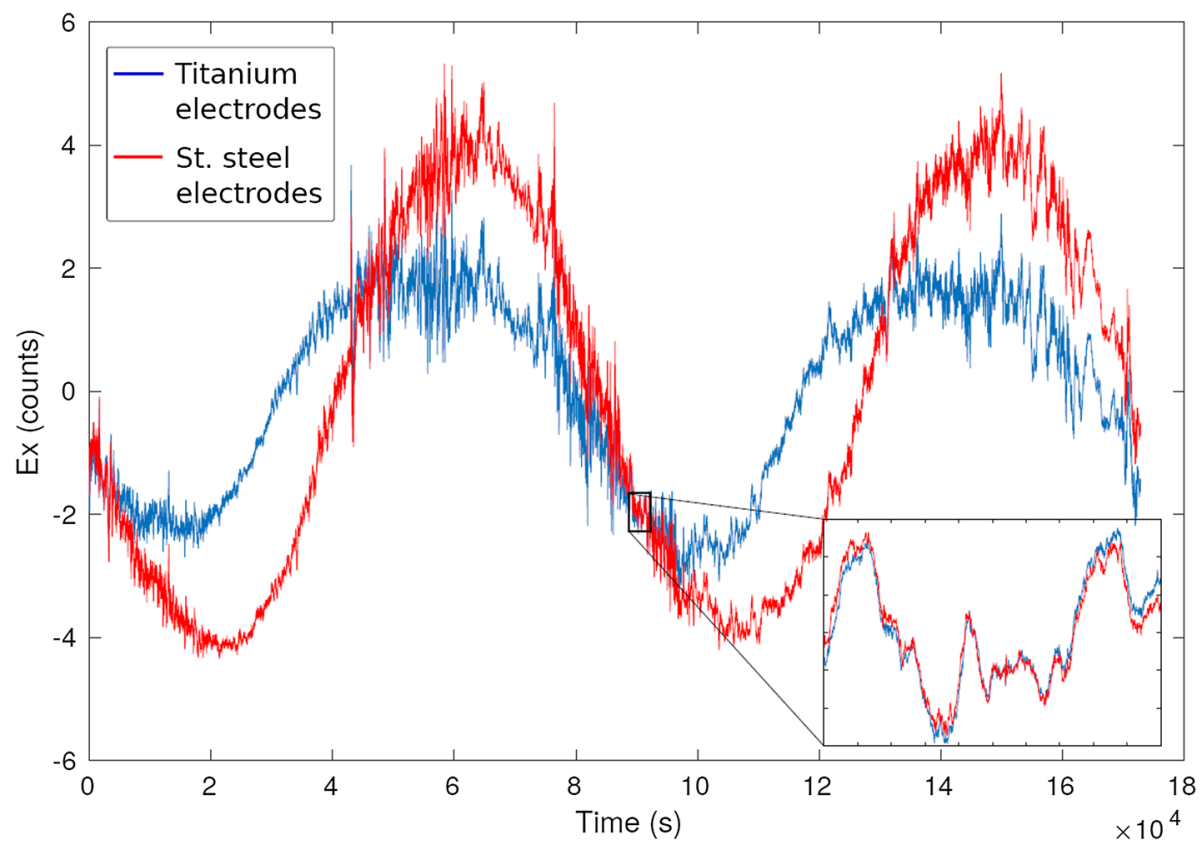

Fig. 7 Example of $\sim 48 \mathrm{~h}$ of time series from the Greenland Ice Cap from adjacent stations $\sim 14 \mathrm{~km}$ apart, the first using titanium electrodes (blue) the second using stainless steel electrodes (red). A diurnal response is present in both the titanium and stainless steel electrodes which have a larger amplitude, though for the period range of interest the two responses show strong correlation (inset). Figure provided by K. Selway after Selway and Conrad (2018) 
to the material properties of the alloyed stainless steel versus the pure titanium metallurgy. Potentially differing geology associated with the $14 \mathrm{~km}$ separation of the two measurement sites is unlikely to be the source of the diurnal difference given the obvious MT signals are of the same size on both metal electrode material types. Further testing would be required to determine the cause of the amplitude variation of the different metallic electrodes; however, the two metals observe MT signals that 'track one another' over the period range of interest for MT measurements, although, the diurnal variation is smaller amplitude on the pure titanium electrodes.

Work in Svalbard (Beka et al. 2015, 2016, 2017a, b) where the measurements were not typically completed on firn or ice, but rather in the underlying soil horizon overlying the permafrost zone used standard $\mathrm{Pb}-\mathrm{PbCl}_{2}$ wet cell porous pot electrodes to which additional salt was added to prevent freezing in the ambient temperature range of -10 to $0{ }^{\circ} \mathrm{C}$ experienced (Smirnov, pers. comm. 2019). Contact resistances in the cold soil were 10-20 K $\Omega$. A saturated salt solution was added at the electrode soil interface as a further effort to prevent freezing of the electrodes (Smirnov, pers. comm. 2019). At measurement locations where the overlying snow cover was too thick to reach the soil layer below, the contact resistance was consistently above $40 \mathrm{~K} \Omega$ (Smirnov, pers. comm. 2019). For site installations in the snow, porous pot electrodes were deployed in 'ice pools' dug in the snow and filled with saturated saline water (Beka 2016). Wannamaker et al. (1996) experimented with chemical electrodes in the firn during work in Central West Antarctica (without adding salt to the environment) and found they were subject to high self-potential, and were outperformed by the titanium electrodes. High-latitude environments are host to fragile ecosystems which may be altered or damaged by the addition of large amounts of a saturated salt solution. As such, this approach may be a concern for those responsible for management of these areas and necessitate more complicated permitting and environmental remediation and reporting requirements. Evans et al. (2005) encountered similar conditions in central Baffin Island, standard terrestrial field practice deployment of wet cell porous pot electrodes was used; they did note that frozen ground associated with permafrost did prevent the installation of vertically oriented induction coils at some measurement locations.

\section{Local Noise Sources}

The earliest investigations of blizzard induced electric fields were a result of static interference on radio antennas (Simpson 1919; Barre 1954; Wishart and Radok 1967). All studies of the Antarctic interior conducted on the polar ice cap (Wannamaker et al. 1996, 2004, 2017; Peacock and Selway 2016; Hill et al. 2019) report difficulties created by wind-generated noise. The noise is not a result of wind-induced motion of the telluric cables as these are quickly frozen in place via a combination of thermal heating of the dark cables melting into the ice and free snow and ice particles being blown into the bipole wire and drifting over. Rather this distortion is the result of wind-induced moving (saltation) of snow and ice particles creating localised snow clouds and ice fogs. The wind-driven movement of snow and ice particles can be separated into three modes: creep, saltation, and suspension (Mellor 1965). Creep is the rolling or sliding of particles along the surface which does not have a meaningful effect in generation of localised charged snow clouds. Saltation is when particles move via bouncing near surface $(<10 \mathrm{~cm})$ trajectories (Schmidt et al. 1999), from which particles can become caught in turbulent eddies and move into the suspension mode of transport (Radok 1968). Suspension is when these particles become entrained and 


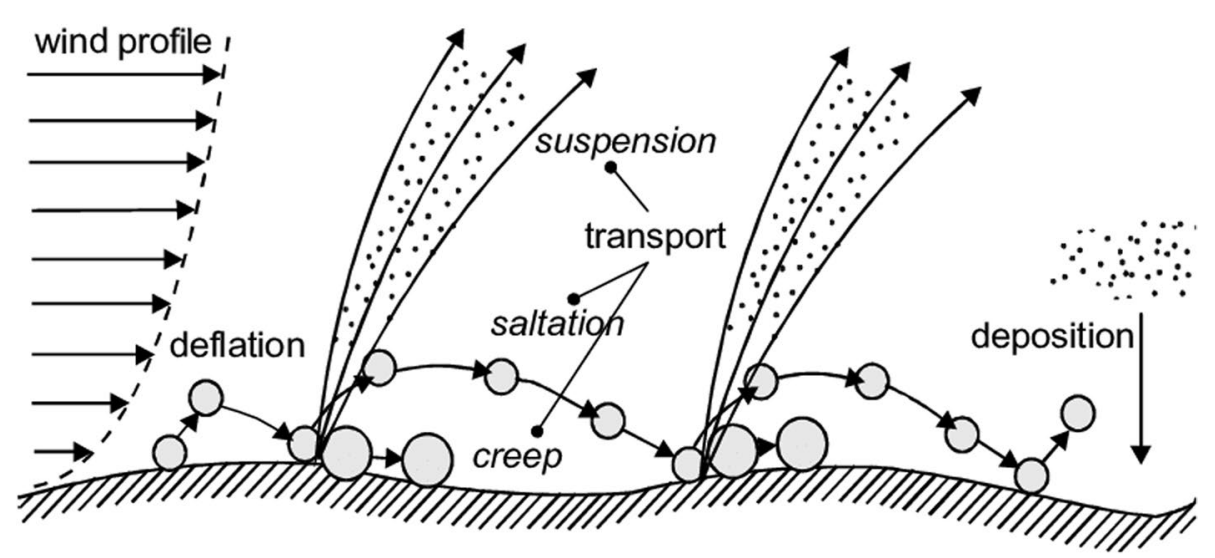

Fig. 8 Schematic illustrating the different phases of wind-driven snow and ice particle motion. Reproduced from Cornelis (2006)

form localised clouds of snow and ice particles (Radok 1968) extending to $\sim 4 \mathrm{~m}$ above the surface (Fig. 8). Snow and ice particles in suspension were the main state responsible for inducing the distortion in the MT response at South Pole (Wannamaker et al. 2004), where macro clouds of suspended charged particles comparable in size to the bipole were observed drifting over the measurement footprint.

Blowing ice and snow particles develop charge differences via the thermoelectric effect which is comprised of three mechanisms: asymmetric rubbing, crystal fragmentation, and air-surface temperature differential (Latham and Stow 1967). The thermoelectric effect is the production of electric charge based on a temperature change or gradient. The mechanism for the thermoelectric effect in snow and ice particles stems from a charge separation which develops as a result of the concentration of $\mathrm{H}^{+}$and $\mathrm{OH}^{-}$ions being proportional to temperature (i.e. increase in temperature result in a large increase in $\mathrm{H}^{+}$and $\mathrm{OH}^{-}$ions). The $\mathrm{H}^{+}$ions are smaller and more mobile within the ice crystals, and are able to more rapidly move to the colder region (Latham 1964).

There are three mechanisms that contribute to the thermoelectric effect that generates the electrostatic force. (1) Temperature gradient develops from asymmetric rubbingwhich is the process of frictional induced differential heating between small and large surfaces (Henry 1953), friction heats the smaller snow or ice particle more than the large surface it is rubbing along. The thermal gradient that develops on the snow and ice particles leads to the colder surface becoming positively charged, while the warmer particles develop a negative charge. (2) The differential cooling of a snowflake's extremities in comparison with the central core causes the cooler extremities to develop a net positive charge. As the snowflake collides with other snowflakes and the surface, the extremities break free of the central core creating small light positively charged particles, while the core is left as a larger and heavier negatively charged particle (Latham and Stow 1967). As wind speed increases, the sublimation rate increases and the collisions become more energetic causing the creation of more charged particles resulting in a larger potential difference (Gordon and Taylor 2009). (3) The temperature difference between the air and surface creates charge through the particles moving towards equilibrating to the air temperature which may be either a cooling or heating of the particle depending on local climatic conditions. Additionally, sublimation may provide a cooling effect on the particle. If the air has a warming 
effect on the airborne particles, the now 'warm' particle will acquire a negative charge when it makes contact with the cool surface (Latham and Stow 1967), and when the air has a cooling effect on the particles they will acquire a positive charge when they make contact with the warmer surface.

A vertical (normal to the surface) electric field is generated by the differential charge created in the suspended particles and the surface snow layer. Measurements of the strength of this electric field have ranged from 1 to $30 \mathrm{kV} \mathrm{m}^{-1}$ at heights from 0.02 to $4 \mathrm{~m}$ above the surface (Schmidt and Dent 1994) and decreases with height (Gordon and Taylor 2009). When considering the maximum electric field strength $30 \mathrm{kV} \mathrm{m}^{-1}$ and maximum observed charge density $-208 \mu \mathrm{C} \mathrm{kg}^{-1}$ (Schmidt et al. 1998), the resulting electrostatic force is equivalent to an acceleration of greater than $0.6 \mathrm{~g}$ (Gordon and Taylor 2009). The electrostatic force is significant when determining the trajectory of snow and ice particles such that they cannot be treated as simple ballistics, and influences their distribution and the transition from movement via saltation to suspension by increasing the saltation height by up to 20\% (Schmidt and Dent 1993; Schmidt et al. 1998).

The sign, magnitude, and distribution of the net charge of blowing snow can be highly variable; however, thermoelectric effects should generally lead to snow and ice particles acquiring a net negative charge when the air is warmer than the surface (typical of summer months) resulting in a large increase in the positive (upward pointing) potential gradient proportional to the wind speed (Simpson 1919). Polarity of the net charge of wind-induced snow and ice particle clouds is not important, only that a local charge distribution is present as the arbitrary charge density distribution can be represented as a sum of elementary charge distributions (Griffiths 1981), leading to a zero mean asymmetric charge distribution along the bipole (Wannamaker et al. 2004).

Saltation of snow and ice particles begins when wind speeds reach $8 \mathrm{~m} \mathrm{~s}^{-1}$ (Schmidt et al. 1999) at which point coherence between the electric and magnetic fields begins to deteriorate (Peacock and Selway 2016) which was observed from 0.2 to $100 \mathrm{~s}$, whereas at South Pole Wannamaker et al. (2004) observed the loss of coherency to $300 \mathrm{~s}$, and Hill et al. (2019) found the entire period band was affected at Mount Erebus. Wannamaker et al. (2004) ran parallel tests at South Pole during windy conditions which demonstrated the loss of coherency by running a test collection with two sets of preamps and telluric cables connected to a single pair of titanium electrodes, and a second collection with two parallel bipoles offset by $\sim 3 \mathrm{~m}$ (Fig. 9). In the test with the common electrodes, the two electric fields are correlated though there is little correlation between the electric and magnetic field, while the test using the two bipoles with the $\sim 3$ m offset shows correlation between the longer period signals. However, there is poor correlation in the high-frequency response between the two electric field observations. Visual observation of the environmental conditions during the parallel test was that the blowing snow and ice particle clouds were distinct around the different electrode locations. These observations demonstrate that the local (bipole scale) high wind speed conditions are the source of a white noise by producing variable local electric fields.

The differing period ranges that the wind-induced electric field noise were observed to affect result from differing the wind conditions in these different study locales. The South Pole was characterised by general storminess (Wannamaker et al. 2004), the East Antarctic coast was affected by daily katabatic winds coming off the polar plateau (Peacock and Selway 2016), and Ross Island was subject to high energy periodic storms (Hill et al. 2019). Wind speed determines the length of time that a given charge anomaly takes to traverse the bipole as well as the size of the charge anomaly (higher wind speeds are associated with larger charge anomalies). The asymmetric charge 


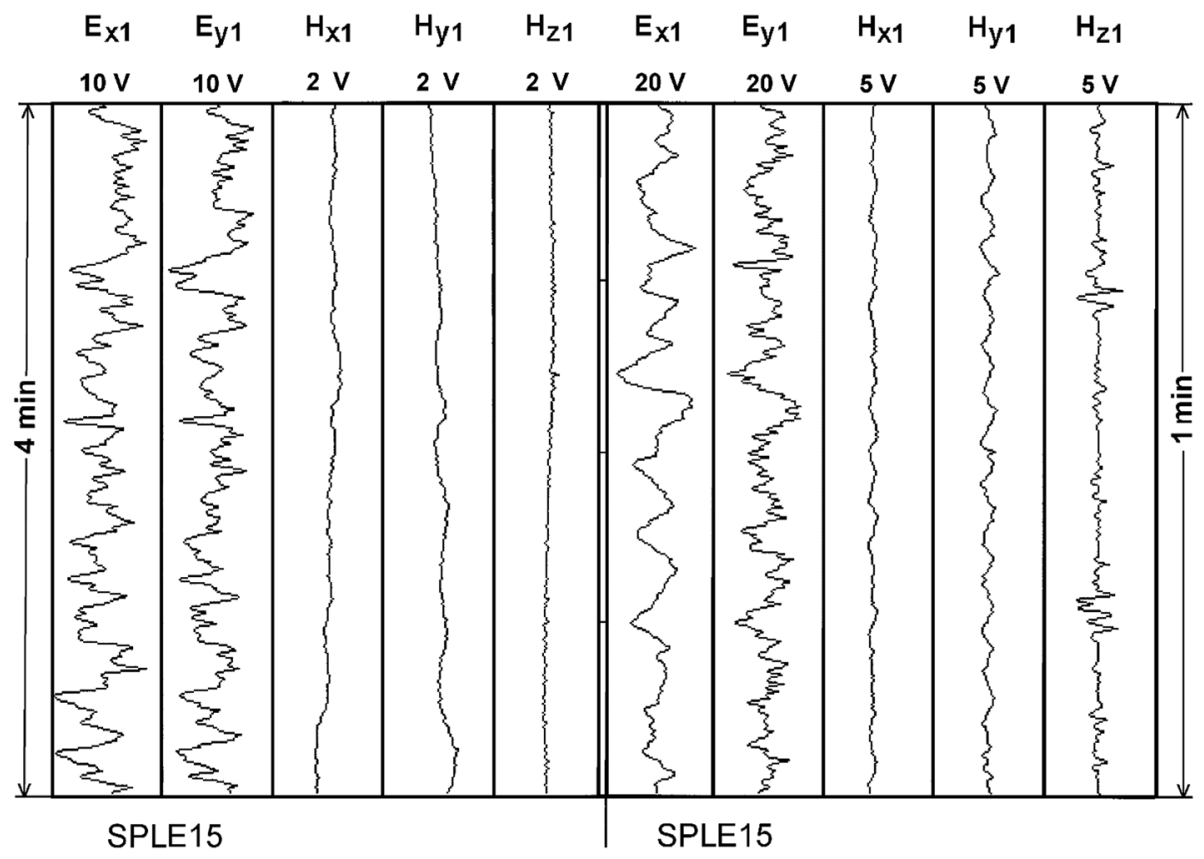

Fig. 9 Parallel bipole test completed local to South Pole to test the wind-induced noise. Left hand panel was recorded using a single electrode pair with two sets of telluric cables, the right-hand panel shows parallel bipoles with $3 \mathrm{~m}$ spacing during a local wind event. The left panel demonstrates that the channels are tracking one another when presented with a common signal, while the right-hand panel shows that small wind-induced effects cause significant distortion of the electric field over short distances. While the two recordings are located in the same place, the two sets of time series are not synchronous. The full-scale voltage range for each channel is displayed below the channel ID. Reproduced from Wannamaker et al. (2004)

anomalies created by the charge separation that occurs in these wind-generated snow and ice particle clouds of comparable size to the bipole length will result in distortion of the observed electric field over a period equivalent to the time it takes the charge anomaly to traverse the bipole (Wannamaker et al. 2004).

The wind-induced noise is localised to individual bipoles without correlation between the $E_{\mathrm{x}}$ and $E_{\mathrm{y}}$ bipoles at a given site or from different sites, as individual charge anomalies are short lived and rapidly varying features that lack coherence over any significant distance. The lack of coherence of the wind-induced noise suggests that significantly increasing the electric field bipoles may overcome the problem for low and moderate wind speed conditions by increasing the signal-to-noise ratio (Wannamaker et al. 2004). Hill et al. (2019) deployed $300 \mathrm{~m}$ bipoles ( $2 \times$ standard bipole length being used) at locations where local wind speeds were known to regularly be high, coupled with long occupation recording to maximise data collection during periods of low wind speed. This approach improved the quality of the responses obtained in high wind speed locations. Practically deploying very long bipoles can be challenging and potentially a safety concern when working in glaciated terrain as the increased site foot print increases the probability of crevasse or other hazards being encountered. 


\section{Logistical Uniqueness}

When planning a field campaign in the polar regions, the increased time and unique challenges associated with working in these environs need to be considered. The polar regions can be some of the most difficult-to-access locations in the world and experience weather systems that can prevent field operations for periods of a week or more at a time. For the cold polar regions, there are support agencies whose entire purpose is to facilitate field operations by providing the logistical support once on site. National Antarctic and Arctic programs have similar operating procedures from personal involvement in field campaigns operating under the umbrella of multiple national programs. The similarities and collaborative resource sharing carried out by differing national programs allow for large projects to be undertaken that are beyond the scope supportable by a single funding agency, and while each national program has their own operational guidelines and requirements they are comparable, for example, being medically qualified for deployment by one program is usually honoured by others. The logistical operational costs for completing field operations are typically blind to the research program; however, the costs associated with operating helicopters and fixed wing aircraft, the number of support staff required, and the complexity of communications in polar regions are all significantly higher than in temperate regions-with logistical support costs comparable to marine ship-based work. The air support and other overland travel infrastructure (tracked vehicles-e.g., piston bully, tuckers, snowmobiles, and haglunds) are heavily subscribed in order to maximise the value of these high cost resources. Use of these resources is assigned based on scientific objectives and prioritisation by the funding and support agencies typically following a just-in-time and minimum resource required model when possible projects that require significant dedicated air support are shifted to operate during the 'night' shift when there is less demand for resources.

Dedicated air support can be required for groups working large distances nearing the operational limits of the aircrafts travel range, or for groups working in locations where for safety reasons having the aircraft remain on site is beneficial (e.g., groups working at high altitude or when the weather is forecast to deteriorate throughout the day). The nature of weather systems in both the Arctic and Antarctic is that they are typically large systems with storm cycles lasting 7-10 days during which wind speeds are often high. This leads to reduced data quality from blowing snow and ice particles, resulting in stations running during these periods often having poor data quality and in need of repeating. The combination of over subscription of resources and weather-induced delays can result in data collection taking two to three times longer than would normally be expected in temperate regions.

The biggest and most important difference when working in the glaciated and high elevation mountain environments characterising polar regions are the additional safety hazards encountered: crevasses, ice falls, illness or injury related to exposure and altitude, fast moving weather systems, and polar bears in the northern hemisphere. Glacier operations and travel has an inherent risk exemplified by two recent incidents on opposite sides of the Antarctic continent - fatal crevasse falls, one during the 2015/16 season near the Australian Davis Station East Antarctica (Fig. 1) in which a helicopter pilot fell into a crevasse at a long established refuelling depot, the second during the 2016/17 season occurred in the McMurdo shear zone near Ross Island (Fig. 1) in which a glaciologist fell into a crevasse on a snowmobile. Field teams operating in glaciated terrain may be required to have a dedicated mountaineer and undergo onsite training for safe glacial travel and crevasse rescue situations including roped travel (both on foot and roped snowmobile travel), arrest and 
rescue of a crevasse fall. Exposure, operations at altitude, and cold environments with fast developing weather systems pose a risk for frostbite, hypothermia, HACE (High-altitude cerebral oedema - the swelling of the brain with fluid), and HAPE (High-altitude pulmonary oedema-the accumulation of fluid in the lungs). Groups working at altitude typically receive basic training in identifying and treating these conditions as part of their onsite Antarctic survival training, with at least two members of each field party normally required to hold advanced first aid training (e.g., Wilderness First Responder or Pre Hospital Emergency Care) if they will be operating remotely (nominally 1-h flight time) from the medical resources of the host research station or support camp for extended periods of time. Supported field camps with multiple events operating in the deep field (those either working at altitudes greater than $3000 \mathrm{~m}$ or $300 \mathrm{~km}$ from the supporting station) usually have a Physician's Assistant deployed as a member of the camp staff.

Fast moving weather systems, operational requirements, or mechanical issues can result in groups failing to be picked up from their field site. In general, when a group is away from their operations base, be that a station, supported or unsupported field camp survival bags are carried with resources for at minimum 3 days; groups operating in more remote or weather affected locations carry resources to enable the group to safely remain for up to a week before retrieval. A large helicopter and fixed wing field camp supporting multiple science events was jointly operated by the United States Antarctic Program and Antarctica New Zealand during the 2010/11 field season in the Central Transantarctic Mountains with multiple science groups operating from this support centre. A helicopter gear box failure lead to the pilots' duty day being reached before all the field groups had been picked upresulting in the only survival bag camp of the season (which was reported in the New York Times); the field team spent the night at their field site and were recovered the following day.

\section{Electromagnetic Studies in Polar Regions}

The use of Electromagnetics in polar regions, where they have been used to investigate a diverse breadth of topics from near-surface groundwater systems to large-scale continental tectonics, is becoming more popular. The relatively simple and minimal logistical support requirements of EM methods compared to other geophysical techniques, coupled with the broad depth range of investigation, have driven this increased popularity. Examples are reviewed from both completed and ongoing studies that demonstrate the geologic importance and impact EM studies are making in polar studies. Additionally, studies illustrating the development and novel approaches of EM use in these regions are discussed. There are of course numerous studies that for space reasons are not discussed, many of which have been mentioned above while discussing the unique challenges associated with data collection in polar regions. The examples are chosen as illustrative of both the type of research questions being addressed and scale of current research programs. The significant contributions made by EM studies on such diverse subjects speak to the future potential of EM methods in these environments.

\subsection{Early Antarctic Studies: Central West Antarctica and South Pole}

The first successful application of interior Antarctic MT was the ANTALITH project (Wannamaker et al. 1996) over the Byrd subglacial basin of Central West Antarctica (CWA) 
(Fig. 1). Antarctica is broadly divided into West and East Antarctica by the Transantarctic Mountains (TAM). East Antarctica which includes the South Pole is described as a stable cratonic block that was a component of a Late Proterozoic super continent (Dalziel and Lawver 2001; Karlstrom et al. 2001) with varying crustal thicknesses greater than $40 \mathrm{~km}$ (Bentley 1991; Clarke et al. 1997, Shen et al. 2018). West Antarctica represents a complex series of accreted terranes and subduction related plutonic rocks that formed since the lower Palaeozoic (Storey and Alabaster 1991). The compressional tectonics responsible for the assembly of West Antarctica ceased and was replaced by extensional processes related to the breakup of Gondwana beginning in the Cretaceous (Storey and Alabaster 1991; Cande et al. 2000). The extensional tectonics of West Antarctica is characterised by punctuated periodic uplift and denudation of the TAM (Fitzgerald and Stump 1997), graben formation in Marie Byrd Land and the Ross Sea (Davey and Brancolini 1995), and volcanism in Marie Byrd Land, Victoria Land, and Horlick Mountains during the Cenozoic (LeMasurier and Rex 1991). A mantle plume under the Antarctic Plate has been proposed as the cause of the Cenozoic volcanism and the driving force of the tectonism (Hole and LeMasurier 1994; LeMasurier and Landis 1996; Behrendt 1999).

In this 'ice-breaking' study, Wannamaker et al. (1996) collected 12 MT measurements, ten of which were along a 54-km-long profile ( $6 \mathrm{~km}$ spacing). This work effectively created the blueprint for successfully overcoming the very high electrical resistivity of the thick $(\sim 2 \mathrm{~km})$ ice sheet by using custom-designed buffer amplifiers. Based on 2D finite element forward modelling of the responses along the ten-site profile, the crust on the whole is quite resistive with two compact conductive bodies embedded. This is characteristic not of thermally elevated extensional regimes where broad-scale low resistivity exists across the lower crust, but rather of sutured metasedimentary packages within fossil compressional terranes (Wannamaker et al. 1996; Boerner et al. 1996; Jones et al. 2005). This was the first result to quantitatively argue for a dormant state of rifting in this area of CWA, and has often been cited as important evidence for this state (Clarke et al. 1997; Blankenship et al. 2001; Winberry and Anandakrishnan 2003, 2004).

Further work in the deep Antarctic interior operating out of the South Pole station (Fig. 1) followed (Wannamaker et al. 2004). This second study was of similar scope again acquiring ten sites over a $54 \mathrm{~km}$ transect $\sim 5 \mathrm{~km}$ out from the station at an orientation of $210^{\circ}$ grid north approximately normal to the trend of the TAM. The 2D inverse modelling identifies a thick $(\sim 1 \mathrm{~km})$ section of high conductivity underlying the ice. This conductive body is interpreted to represent porous sediments of the Beacon Supergroup, and explains the lack of seismic reflection arrivals seen by Bentley (1973). Moving through the crustal column, the conductive sediments are underlain by a resistive middle crust, while at depths of $\sim 30 \mathrm{~km}$ the resistivity decreases. The low resistivity at the base of the crust and uppermost mantle differs from the electrical structure typical of stable cratonic lithosphere. The low resistivity at the base of the crust is interpreted to be a result of underlying active tectonic processes relating to the uplift and support of the polar plateau with the resultant presence of high-temperature fluids and or melting (Wannamaker et al. 2004), consistent with heat flow estimates for the region of $\sim 50 \mathrm{~mW} \mathrm{~m}^{-2}$ (Siegert 2000). The authors suggest that deep lithospheric plume processes could be the dominant cause of the elevated thermal anomaly. However, in addition to a plume-related cause, they also suggest that the thermal anomaly could result from enhanced thermal encroachment driven by a non-uniform degree of extension versus depth. Recent work shows a low P-wave upper mantle zone local to South Pole (Hansen et al. 2014) and rapid basal ice melting from radar data (Jordan et al. 2018a), supporting non-uniform extension as the source of the thermal anomaly rather than plume-related activity. In both of these early studies, sites were accessed solely 
by overland travel primarily using snow mobiles with towed Nansen and Siglund sleds at Central West Antarctica, with the addition of a central recording hut towed by a Tucker SnoCat, with telemetered MT recording systems on Nansen sleds $3 \mathrm{~km}$ either side at South Pole.

\subsection{BEAR and MaSca Array MT Experiments, Fennoscandia}

The lithospheric structure of Fennoscandia has long been of interest to the EM community (e.g., Kaikkonen et al. 1983; Jones 1983; Pajunpaa 1987; Rasmussen et al. 1987; Korja and Hjelt 1993; Korja and Koivukoski 1994; Brasse et al. 2006; Korja et al. 2008). More recently, the BEAR (e.g., Korja et al. 2002; Varentsov et al. 2002) and MaSca (e.g., Cherevatova et al. 2015a, b) experiments were focused on resolving crustal and upper mantle lithospheric structure of the Fennoscandian shield, and identifying the lithosphere-asthenosphere boundary. BEAR data collection comprised of 46 long-period MT and 20 geomagnetic depth soundings recording simultaneously (Lahti et al. 2005), while the MaSca array included 59 synchronous long-period MT and 220 broad-band MT sites (Cherevatova et al. 2015a), deployed using standard terrestrial field practice. The upper crust is in general resistive which is attributed to differing processes: Archaean gneisses in the north; the resistive Svecofennian volcanic belt in the east; and in the south and central zones the entire crust is predominantly resistive intrusive granitoids (Cherevatova et al. 2015b). Two localised upper crustal conductive zones are attributed to result from shallow graphite shales in the Skelleftea district and the Kittila greenstone belt which is host to both graphite and sulphide-bearing schists (Cherevatova et al. 2015b). The middle-to-lower crustal conductive zone underlying the northern extent of the Svecofennian volcanic province is attributed to the presence of graphite-bearing rocks and sulphides (Cherevatova et al. 2015b). The lithosphere is thickening to the south and reaches a maximum thickness of $\sim 300 \mathrm{~km}$ for the Paleoproterozoic Svecofennian Domain, with a thickness for the Archaean lithosphere of 200-250 km (Cherevatova et al. 2015a), matching the thickness reported previously by Jones (1983) and Korja (2007). However, the assertion of Korja (2007) that there is a thinning of the lithosphere towards the Atlantic (westward) is not observed in the more recent higher-density data set (Cherevatova et al. 2015a). As discussed previously, a series of papers discussing the validity and bounds of the plane wave assumption were also completed as part of the BEAR and MaSca experiments (Korja et al. 2002; Varentsov et al. 2002; 2003a; b; Lahti et al. 2005; Sokolova et al. 2007; Cherevatova et al. 2015a, b).

\subsection{Airborne EM: McMurdo Dry Valleys, Antarctica}

The McMurdo Dry Valleys (Fig. 1) are the largest snow- and ice-free areas in Antarctica which are classified climatically as a polar desert (Doran et al. 2002). The Transantarctic Mountains are a barrier preventing the East Antarctic Ice Sheet (Fig. 1) from flowing into these valleys, the largest of which extend to the Ross Sea coast. The ephemeral streams and rivers (e.g., Onyx River) which form during the warmer summer months coupled with persistent ice-covered lakes are unequivocal evidence that there is a significant amount of water present in the Dry Valleys (Foley et al. 2016). A series of papers (Dugan et al. 2015; Mikucki et al. 2015; Foley et al. 2016) report the results of an airborne (helicopter) time-domain electromagnetic survey flown in November 2011 using the SkyTEM system (Sørensen and Auken 2004). Previously unknown regional low-resistivity zones were identified (Fig. 10) at depths of 150-250 m beneath the surface (Dugan et al. 2015; Mikucki 
(i)

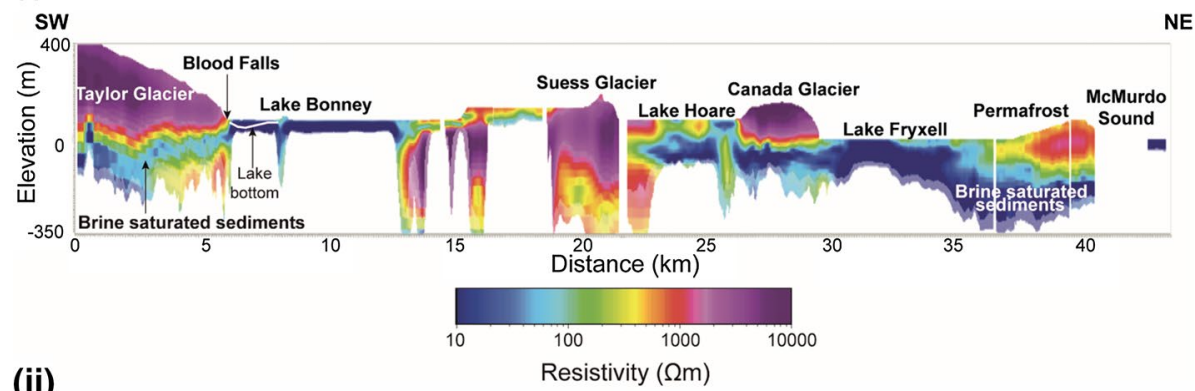

(ii)

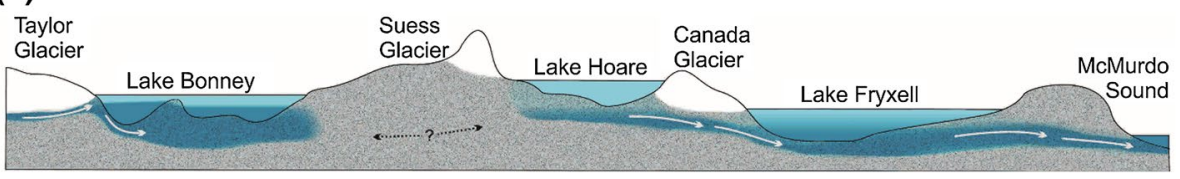

Fig. 10 i Airborne electromagnetic resistivity model of the Taylor Valley. Low resistivities extending from McMurdo Sound to Lake Hoare are interpreted to result from hydrological connectivity of brine in sediments extending from the coastal margin inland and beneath the Canada Glacier. Continuing in land, resistivities increase below the Suess Glacier and Lake Bonney though the resolution depth in the Seuss Glacier and Lake Bonney area is reduced. The low resistivity observed further inland in the Bonney Basin again is interpreted to represent connectivity of brine-rich sediments below the Taylor Glacier and proglacial Lake Bonney at the glacier terminus under Blood Falls. ii Conceptual model for hydrologic subsurface flow and interconnection between the two distinct regions of subsurface brine in the Taylor Valley, the presence and nature of a connection between Lake Bonney and Lake Hoare could not be identified and is marked by '?' Reproduced from Mikucki et al. (2015)

et al. 2015; Foley et al. 2016). The extensive zones of low resistivity are interpreted as porous geologic materials containing hyper-saline fluids (the concentration of these saline brines occurs through the process of freeze concentration termed 'cryoconcentration'). Both Mikucki et al. (2015) and Foley et al. (2016) suggest that these brines are connected with surface lakes, subglacial regions, and the Ross Sea (Fig. 10). The contiguous nature of the low-resistivity zone with these major surface features implies the presence of a complicated and previously unknown or unconsidered hydrogeologic system capable of potentially transporting solutes between these different systems. This large briney aquifer presents a potentially viable microbe habitat in a region previously thought to be inhospitable to microbial communities and may be the best analogue for potential subsurface habitats on Mars and the conditions that would have been present during a Snowball Earth environment (Mikucki et al. 2015). Airborne techniques have a depth of investigation in polar regions of $\sim 350 \mathrm{~m}$ (Dugan et al. 2015; Mikucki et al. 2015; Foley et al. 2016), making them useful tools to investigate the shallow groundwater systems in areas that are not overlain by thick snow and ice. Their use in the cold polar regions of Antarctica and Greenland is as such limited to where they can be deployed in areas free of ice sheet and thick glacial cover (primarily in coastal areas). In warm polar regions, there is far more scope for employing airborne techniques as there is not the $>1 \mathrm{~km}$ of overlying snow and ice cover. 


\subsection{Poker Flats, Fairbanks, Alaska, USA}

When data are collected within the auroral oval as discussed above, workers have consistently identified time segments that adhere to the plane wave assumption to determine the MT transfer functions. This approach has been favoured because of the difficulty of determining the structure of the time-varying non-planar magnetic source field, while the MT measurements are collected. An ongoing study north of Fairbanks in central Alaska (Fig. 1) takes advantage of the Poker Flat Incoherent Scatter Radar (PFISR), operated by the University of Alaska at Fairbanks Geophysical Institute on behalf of the Goddard Space Flight Center to produce images of the ionosphere at a series of different altitudes above ground level. Schultz et al. (2016) use the PFISR data to constrain the intensity and orientation of the Hall currents at the base of the ionosphere, which can be used as input in a direct waveform inversion of the MT observations in the time domain to explore the crustal and upper mantle structure of the Alaskan flat subduction backarc transition to cratonic North America. An array of 25 long-period instruments was deployed for $\sim 4$ months in late 2015 , using a '+' survey geometry centred under the PFISR. The proximity of the auroral oval can be seen in the MT responses at periods greater than 2000s. The MT responses are being modelled both using a conventional frequency domain inversion approach and using the waveform time-domain approach being developed. The waveform time-domain approach is numerically expensive given the complexity involved in solving for both the time-varying source field structure as well as the invariant resistivity structure of the crust and upper mantle. However, the increased detail of the source fields may allow improved resolution of subtle structure in both the crustal and mantle.

\subsection{Deception Island-Antarctic Islands}

A small seven-site MT survey was undertaken to investigate the structure and melt distribution of the Deception Island magmatic system (Pedrera et al. 2012). Deception Island is an active volcanic caldera located in the South Shetland Archipelago (Fig. 1) 120 km north of the Antarctic Peninsula. The most recent eruptions occurred in 1967, 1969, and 1970 causing the evacuation of the islands research stations and destroying both the British and Chilean stations. Quaternary volcanism of the Shetland Group resulted from the extensional opening of the Bransfield Basin due the slowing and end of subduction during the Cretaceous, leading to roll back at the South Shetland trench (Galindo-Zaldívar et al. 2004). The Shetland Group volcanic vents are mostly submarine; Deception Island, located at the Southern margin of the Shetland Block, is the most active (Smellie 2001). Currently the system has significant geothermal activity and ongoing shallow seismicity, with tomographic results indicating the presence of a shallow crustal magma reservoir (Zandomeneghi et al. 2009). A 2D inverse model and 3D forward model were constructed from the small MT survey, both of which require a low-resistivity zone interpreted to represent a magma reservoir consisting of a combination of partial melt and thermally elevated magmatic fluids (Pedrera et al. 2012). The $\sim 1000 \mathrm{~km}^{3}$ volume of the magma reservoir inferred from the MT modelling (Pedrera et al. 2012) is significantly larger than previous estimates which varied from $20 \mathrm{~km}^{3}$ from seismic studies (Ben-Zvi et al. 2009) to $\sim 30-60 \mathrm{~km}^{3}$ based on eruptive products (Smellie 2001; Marti et al. 1996). Given the complicated topography and bathymetry of the region and limited workable terrain and site locations on the island, future work to address this discrepancy should focus on collection of marine MT 
measurements and a 3D analysis using an algorithm that is able to accurately incorporate both the topography and bathymetry of the region.

\subsection{Ice Sheet and Glacier Dynamics}

Larger scale variations in the bulk resistivity of glaciers and ice sheets can be caused by a number of different properties of the ice volume: variable ice density, temperature, impurity characteristics and the presence of other organic and non-organic materials, shear strain rates, rate of basal melting, and seasonal variations in the near-surface firn temperature profile (Kulessa 2007). Smaller scale variations in bulk resistivity can result from the presence of crevasses (Hochstein 1967; Bentley 1977; Vogtli 1967) and can either be a resistive or conductive anomaly reflecting the nature of the material filling the crevasse. A buried crevasse in an ice shelf (a thick floating platform of ice that forms where a glacier or ice sheet flows down to a coastline and onto the ocean surface) may be filled with a mix of snow, ice, and frozen sea water will produce a conductive anomaly, while a crevasse in an ice sheet or glacier where sea water is not present in the fill material would produce a resistive anomaly (Middleton 2000).

A broad inverse proportionality exists between ice temperature and resistivity (i.e. decrease in temperature results in an increase in resistivity) though percolation and refreezing of meltwater and changes in crystal geometries are dependent on temperature and affect bulk resistivity (Reynolds and Paren 1980, 1984; Shabtaie and Bentley 1994). Heat flow from below will promote basal ice sheet melting if it is high enough to raise temperature to the melting point for the given pressure (depth) conditions. Given enough basal melt, a change in resistivity at the base of the ice column due to the phase change from solid ice to liquid water may allow differentiation between ice sheets with active basal melting and those without. Theoretically then the resistivity at the base of the ice column coupled with estimates of rate of basal melt from complimentary studies (e.g., Jordan et al. 2018a, Jordan et al. 2018b) can provide information on heat flow. Further the resistivity is dependent on the crystal structure and size and could be used to trace a particular boundary within the ice volume of interest. While there is significant scope for applying high-frequency MT data to investigations of ice sheet, shelf, and glacial dynamics, in practice collection of the required data set may be difficult. In Antarctica, there is little-to-no lightning activity (Collier et al. 2011); observed signal associated with lightning activity thus originates at large distances and the highest frequency that reliably has the required spectral energy is $\sim 100 \mathrm{~Hz}$ (Wannamaker et al. 2017; Hill et al. 2019). Grounded active source approaches have struggled with injecting the required current into the high impedance firn and ice. However, new sensor and instrument generations may enable collection of the high-quality audio magnetotelluric data required for ice property investigations. Current work on the Whillians ice stream shows improved high-frequency response using the latest generation Phoenix systems (Key, pers. comm. 2019). Note that large series impedance generated by, e.g., high electrode contact resistance will make a low-pass filter with any shunt capacitance acting at the first amplifier input, which may require calibration as frequency or series impedance becomes large. When necessary, this calibration requires knowledge of the shunt capacitance acting at the input of the first amplifier, and an in situ measurement of the series impedance.

Determining the thickness of the overlying ice coverage and characterising the shallow structure of the basal region is a further application. Wannamaker et al. (2017) image a thin $(\sim 5 \mathrm{~km})$ near-surface low-resistivity zone underlying measurements completed on the Ross 
Ice Shelf which has an average thickness of $\sim 800 \mathrm{~m}$, and floats on an estimated $300-400 \mathrm{~m}$ of sea water (Greischar and Bentley 1980). The conductance of this shallow zone of low resistivity $(\sim 1000 \mathrm{~S})$ is comparable to the conductance of the estimated sea water column (300-400 m), and saturated sediments below (Wannamaker et al. 2017). The hydrologic system underlying large ice sheets and glaciers can have a significant effect on the dynamics of the overlying ice motion (e.g., Kamb 1987; Bell 2008). In a synthetic study, Key and Siegfried (2017) explore the feasibility of investigating the processes occurring at the basal zone of ice sheets using EM approaches that have been applied to hydrologic systems in temperate regions. They show that with favourable data quality (data errors of $1 \%$ at high frequencies up to $1000 \mathrm{~Hz}$ ), a thin local $3 \Omega \mathrm{m}$ subglacial lake of $\sim 5 \mathrm{~m}$ thickness and $2 \mathrm{~km}$ lateral extent would be detectable under $\sim 1 \mathrm{~km}$ of overlying ice sheet using MT or FDEM. Prior efforts collecting EM data in these regions suggest an active source technique in conjunction with MT could be beneficial, as obtaining the quality high-frequency data used in the synthetic studies has been challenging for both passive and active approaches alone.

\subsection{Denali Fault, Alaska Range, USA}

In late 2002, a sequence of large earthquakes occurred on the Denali Fault system in central Alaska (Fig. 1) culminating in the November 3rd Mw 7.9 strike slip earthquake, one of the largest in the last 150 years in North America, which had a rupture length of $340 \mathrm{~km}$ (Eberhart-Phillips et al. 2003). The Denali Fault is a right lateral strike slip fault running $1500 \mathrm{~km}$ (longer than the San Andreas Fault at $1200 \mathrm{~km}$ ) from Northwestern British Columbia to central Alaska. In response to this earthquake sequence, a combined analysis of multiple geophysical data sets (including MT) was conducted and integrated with geological results (Fisher et al. 2004). The 2002 Denali Fault earthquakes epicentre latitude of $\sim 63^{\circ} 511^{\prime} \mathrm{N}$ meets the geographic definition of a polar region; however, MT data collection tactically followed standard terrestrial field practice during the summer months when the ground was free of significant snow and ice cover, with the time-series processing completed using the approach of Egbert (1997). Wisely, the majority of studies conducted in polar regions seasonally free of snow and ice cover are timed to exploit this period for data collection. Combining results from the MT and seismic reflection experiments showed good correlation between major anomalies of the MT 2D inverse modelling and the prominent reflectors. A low-resistivity zone directly underlying the surface trace of the Denali Fault begins at a depth of $\sim 10 \mathrm{~km}$ and extends through the base of the model section. When the resistivity model is compared to those of other major strike slip systems like the San Andreas (Unsworth et al. 2000; Bedrosian et al. 2002), the presence of low resistivity underlying the surface fault trace is common to both; however, the low resistivity is much shallower at the San Andreas and is attributed to meteoric water influx which is unlikely to be the cause of the low-resistivity zone underlying the Denali Fault. What the two systems do have in common is an absence of seismicity in the low-resistivity features. Two possible causes for the low-resistivity zone that outlines the weakened suture zone and Denali Fault at depth were examined: (1) carbon films and (2) presence of fluids (Fisher et al. 2004). The presence of carbon films can explain the low resistivity, but has no bearing on the lack of seismicity and the shallower cut-off depth for seismicity associated with the Denali Fault. The presence of fluids would have an effect on the presence of seismicity as it has been shown that the presence of high-pressure fluids can reduce fault friction (Byerlee 1993). 


\subsection{Erebus and the Terror Rift, Ross Island, Antarctica}

Mount Erebus on Ross Island (Fig. 1) denotes the southern end of the Terror Rift, and is the world's southernmost active volcano (Oppenheimer and Kyle 2008). The Mount Erebus lava lake and recent erupted lava flows have an unusual phonolite composition rich in sodium and potassium. Gas emissions from the lava lake are unusually rich in $\mathrm{CO}_{2}$ compared to subduction volcanoes (Kyle et al. 1992; Oppenheimer and Kyle 2008). Phonolite magmatic systems, with their ultra-alkalic and silica under-saturated compositions, unique plumbing and liquid lines of descent, and diverse volatile influences are important probes into upper mantle source regions. Phonolites are typically associated with zones of major crustal extension like the West Antarctic and East African rifts or hot spot environments, but can occur in other settings and are capable of producing violent eruptions (Self et al. 2004; Scaillet et al. 2008), and may play an important role in the formation of rare earth element deposits (Long et al. 2010). Well-known examples exist in the East African Rift, Mounts Kilimanjaro, Kenya and Nyiragongo (Chakrabarti et al. 2009; Nonnotte et al. 2011), Devils Tower, USA (Robinson 1956; Závada et al. 2011), and Tenerife (Ablay et al. 1998), among others. A phonolitic eruption destroyed Pompeii in 79 AD (Scaillet et al. 2008), a second caused over 50,000 deaths in the 1815 Tambora eruption in Indonesia (Self et al. 2004), an eruption that significantly affected the global climate (Self and Blake 2008).

Petrologic studies suggest that the phonolite magma forms by fractional crystallisation from a parental basanite melt in stacked magma chambers through the crust (Giggenbach et al. 1973; Kyle et al. 1992; Moussallam et al. 2013), leading to a model of magma genesis and transport from an upper mantle source zone through upper crustal pre-eruptive storage and eruption. The parental basanite forms by low degrees $(<5 \%)$ of partial melting of highly metasomatised peridotite with alkali-rich components (e.g., phlogopite and amphibole) at upper mantle depths of $\sim 100 \mathrm{~km}$ as the upwelling mantle decompresses. The phonolite, which is a $25 \%$ residual liquid from the basanite, resides in a shallow $(<5 \mathrm{~km})$ magma chamber (Fig. 11). This petrologic model for phonolite magmatic evolution has never been tested using geophysical methods that can directly image the deeper magmatic system. A large 3D MT study has been carried out (Hill et al. 2019) to test current models for the Erebus magmatic system and place it in a regional tectonic framework as a step towards understanding the origin and mechanics of these ultra-alkalic systems globally.

\subsection{Svalbard Archipelago, Norway}

The Svalbard Archipelago in the North Sea located approximately at the midpoint between continental Norway and the North Pole is one of the most northerly permanently occupied communities in the world. The geological and stratigraphic framework for Svalbard is well understood (e.g., Faleide et al. 2008; Henriksen et al. 2011) as an uplifted segment of the Barents Shelf providing a valuable proxy for understanding hydrocarbon reserves elsewhere in the region, making Svalbard an attractive location for further geophysical investigation. A series of papers, motivated by a desire to shift power generation away from the burning of fossil fuels, discuss the geothermal resource potential, crustal structure, and potential for $\mathrm{CO}_{2}$ sequestration in the region based on MT and TEM results (Beka et al. 2015, 2016, 2017a, b). Data collection was done primarily in soil by digging through the surface snow cover. When 


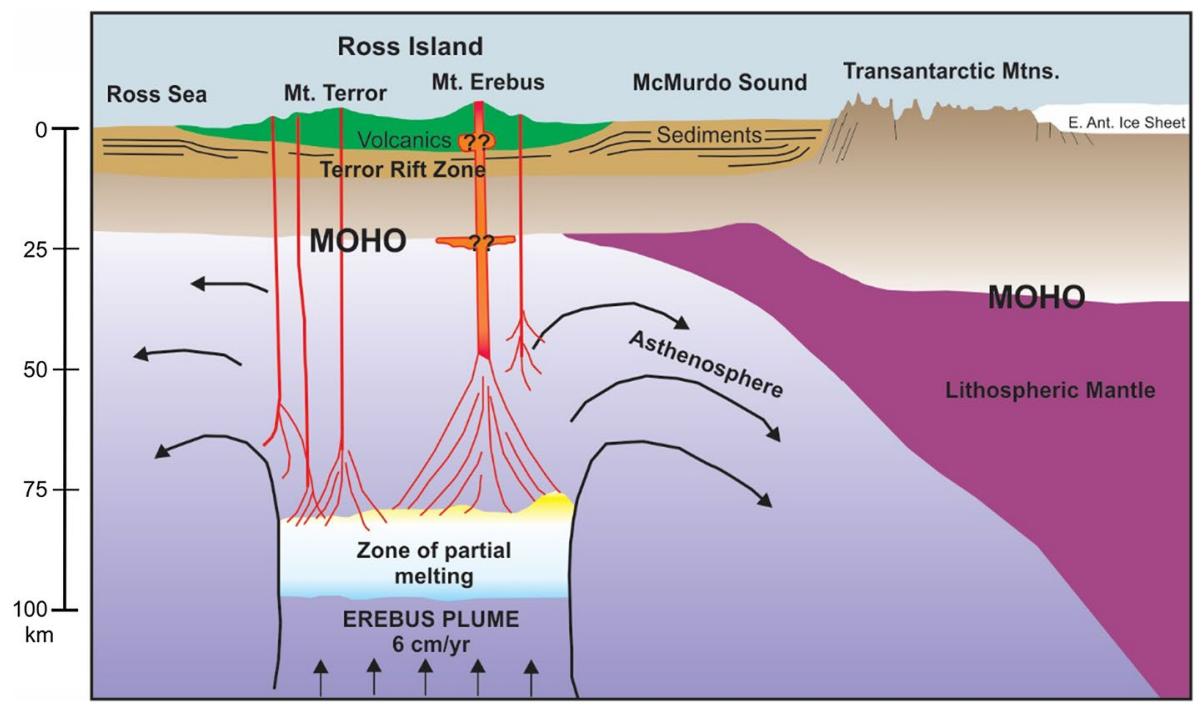

Fig. 11 Schematic model for generation of phonolite melt based largely on petrological and geochemical studies. Imaging the source zone within the upper mantle and the ascent path is one of the aims of the ongoing MT work. Modified from Kyle et al. (1992)

it was not possible to reach the underlying soil, measurements were made in the snow as described above (Smirnov, pers. comm. 2019). The shallow depth of investigation compared to the effective source distance (100-120 km) led Beka et al. (2015) to conclude that the plane wave requirement was satisfactorily met. MT results local to the largest population centre Longyearbyen identified a conductivity structure which is suggested as favourable for geothermal heat storage with a zone of high conductivity in the mid-crust 'sealed' by overlying and surrounding resistive bodies (Beka et al. 2016). Elevated heat flow rates ranging from 80 to $130 \mathrm{~mW} \mathrm{~m}^{-2}$ have been reported for the area (Vagnes and Amundsen 1993; Khutorskoi et al. 2009; Slagstad et al. 2009; Pascal et al. 2011) due to local deep faulting, and a thinned $(\sim 100 \mathrm{~km})$ lithosphere (Bergh and Grogan 2003) combined with the local conductivity structure makes further evaluation of the areas geothermal resource potential warranted. Further a near-surface resistive layer extending to a depth of $\sim 120 \mathrm{~m}$ represents the permafrost zone of primarily unconsolidated gravels (Beka et al. 2016); however, there is significant heterogeneity in the thickness of the permafrost layer with a max depth of $\sim 250 \mathrm{~m}$ and a general thinning westward (towards the coast). The suitability of a site close $(\sim 12 \mathrm{~km})$ to Longyearbyen for $\mathrm{CO}_{2}$ sequestration from the local coal burning power plant was assessed using a subset of the MT data (Beka et al. 2015) coupled with a TEM data set acquired in 2015 (Beka et al. 2017b). The combined TEM and MT data set allowed improved delineation of the permafrost base at $\sim 200 \mathrm{~m}$ and corroborated the structure of seismic and borehole data-it was concluded that to further identify and map the volume of the potential storage reservoir 3D EM data collection would be required (Beka et al. 2017b) including CSEM with its increased sensitivity to resistive anomalies. 


\subsection{Central Transantarctic Mountains, Antarctica}

The Transantarctic Mountains are the world's largest rift shoulder $3500 \mathrm{~km}$ in length and topographic relief exceeding $4000 \mathrm{~m}$ (Stump 2011). The TAM separates the continent into East and West Antarctica, divides their associated ice sheets, and exemplifies tectonism. The mechanics of the tectonism of the TAM may affect ice sheet stability and climatic trends, associate alkaline volcanism and resource potential, and the underlying mantle properties such as viscosity and heat flow that influence uplift and deformation. However, the mechanism of uplift and support of large extensional mountain belts like the TAM remain equivocal. To differentiate the importance of mechanical versus thermal sources of support, a 550-km-long MT transect spanning the central TAM (Fig. 1) was completed (Wannamaker et al. 2017), the first large-scale survey of the Antarctic Interior of comparable scope as studies of analogous tectonic processes at non-polar latitudes. Differing geodynamical uplift models for the TAM have been proposed: (1) a low-density crustal root based on gravity data-in line with isostatic models incorporating a thick East Antarctica lithosphere (Huerta and Harry 2007; van Wijk et al. 2008); (2) thermal buoyancy uplift processes resulting from lithospheric replacement with hot less dense asthenosphere (LeMasurier and Rex 1991), varying heat sources including magmatic under-plating (Fitzgerald et al. 1986; van der Beek et al. 1994), enhanced lower crustal heat production (Huerta 2007), conductive warming from West Antarctica (Stern and ten Brink 1989; ten Brink et al. 1997), and small-scale convection systems resulting from the Ross Sea rifting leading to asthenospheric upwelling (Hansen et al. 2014; Heeszel et al. 2013; Brenn et al. 2017; Lawrence et al. 2006); (3) non-thermal uplift via long wave length $(\sim 500 \mathrm{~km})$ cantilevered flexure (Yamasaki et al. 2008).

Modelling of the transect was completed using the 3D finite element code HexMT (Kordy et al. 2016a, b) as significant 3D effects are present in the data set. The best fitting model (Fig. 12) contains multiple significant structures used to eliminate different potential uplift models. High resistivity $(>1000 \Omega \mathrm{m})$ underlies the TAM front to depths of $\sim 150 \mathrm{~km}$, which at depths exceeding $200 \mathrm{~km}$ falls to under $100 \Omega \mathrm{m}$ until the $410 \mathrm{~km}$ phase discontinuity. Several compact low-resistivity bodies are present underlying the polar plateau including a large quasihorizontal zone underlying the grid north-eastern end of the profile, while to the grid southwest of the TAM adjacent to the high-resistivity package a sub-vertical low-resistivity zone extends through the crust into the upper mantle. The sub-vertical low-resistivity zone is representative of concentrated rift necking and may be the locus of minor basaltic under-plating. The lower crustal low-resistivity horizontal body to the northeast of the profile is interpreted to denote a Precambrian metasedimentary domain. The high resistivity underlying the TAM implies a cold stable state well into the upper mantle ruling out active thermal support of this portion of the TAM, while there is minimal contribution from a crustal root, and the timing of West Antarctic regional rifting is inconsistent with timing required for simple isostatic uplift (Fitzgerald 2002; Miller et al. 2010). The elimination of the alternate support models for the central TAM suggests that a non-thermal, flexural cantilever mechanism is most likely mechanism for the uplift and support (Wannamaker et al. 2017).

\section{Discussion and Conclusions}

The polar regions, while typically free of significant anthropomorphic noise sources, pose significant challenges for MT data collection with non-planar source effects, high contact resistance, and wind-induced electric field noise that can cause distortion and data 

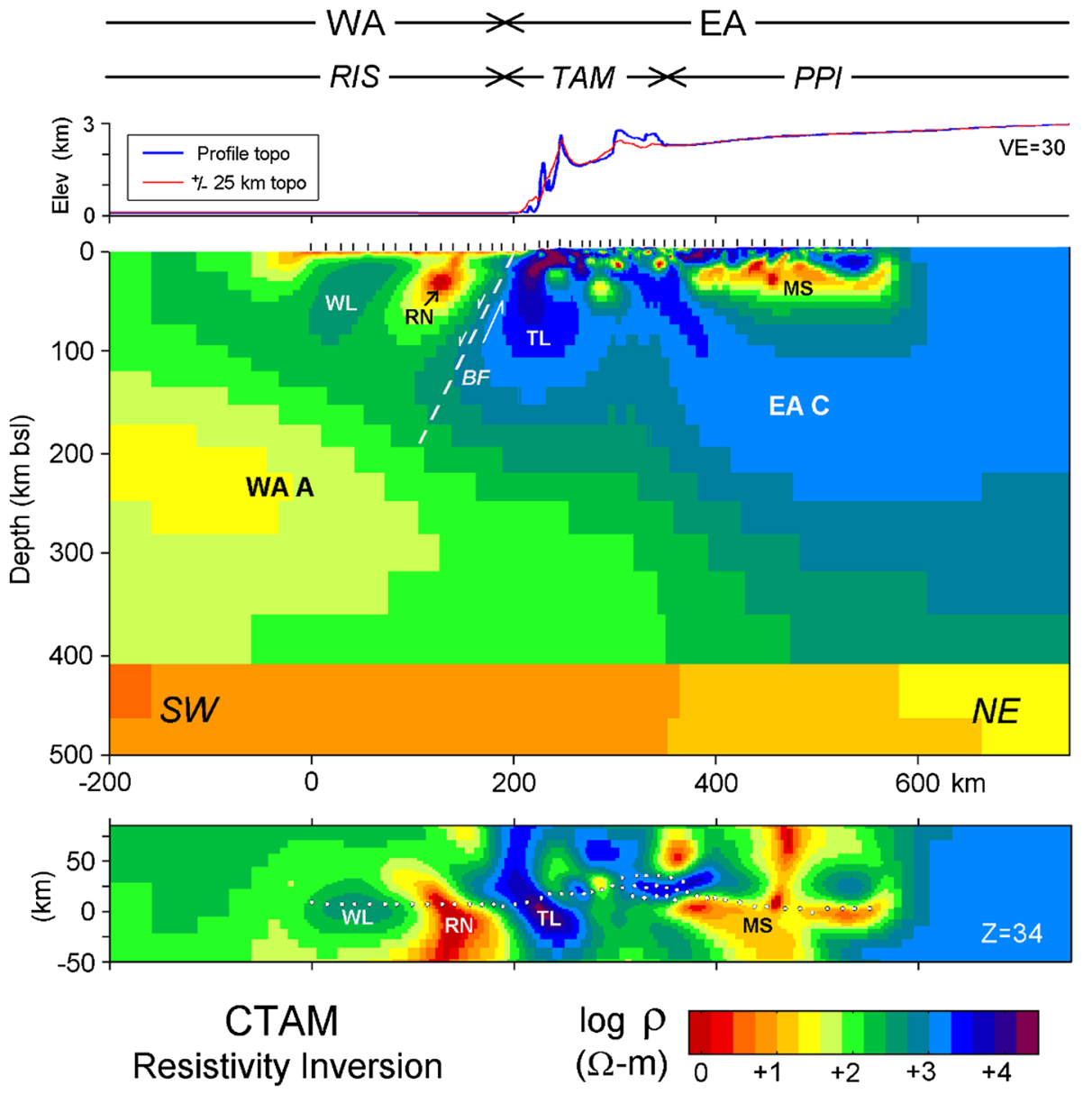

Fig. 12 Three-dimensional resistivity inversion model for the central Transantarctic Mountains. Physiographic regions include West Antarctica (WA), East Antarctica (EA), Ross Ice Shelf (RIS), Transantarctic Mountains (TAM), and Polar Plateau (PPl). Cross-sectional view is slightly meandering to pass through stations of the main profile. Interpreted model features are the West Antarctic lithosphere (WL), active rift necking (RN), regional boundary fault (BF, schematic), TAM lithosphere (TL), Precambrian metasedimentary domain (MS), West Antarctic asthenosphere (WA A), and East Antarctic craton (EA C). Plan view in lower panel is shown at depth of $34 \mathrm{~km}$ over a width of $135 \mathrm{~km}$, with MT stations as white dots. Reproduced from Wannamaker et al. (2017)

quality degradation needing to be considered and overcome. In addition, survey design must include consideration of access feasibility, glacier and mountaineering hazard management, and management of the weather and environmental conditions. Some of these challenges are not exclusive to polar regions; however, cold polar regions are unique in being subject to them all. Non-planar source effects need to be considered by those working in proximity to the equatorial electro-jet. High contact resistances will be encountered on temperate glaciers and permanent large snow fields, as well as in hot sand deserts where dry sands can have contact resistances greater than $1 \mathrm{M} \Omega$. Hot arid desserts are the most similar environment as far as being subject to multiple of the issues faced in cold polar 
regions, as wind-induced motion of sand particles is analogous to the wind-induced motion of snow and ice crystals generating local electric fields, while also having extreme environmental conditions that need to be properly managed.

Electromagnetic methods, with their wide bandwidth of investigation, straightforward and economical logistical support requirements are becoming seen as an increasingly important and powerful tool in polar studies. The wide bandwidth and resultant depth of investigation possible has meant electromagnetics has played an important role in studies ranging from identification of hidden crevasses, shallow groundwater systems, fault dynamics, volcanic systems, and large-scale rift dynamics and tectonics. Both the north and south polar regions are locations to address intriguing fundamental outstanding questions in Earth sciences ranging from large-scale tectonism (rift evolution and extensional mountains, e.g., West Antarctic Rift System), mantle plume dynamics (e.g., Iceland hotspot and how it relates to the current tectonism in Greenland and ice sheet stability, as well as driving the Icelandic volcanism), to economic resource evaluation (e.g., kimberlite process and transport of diamonds in both Northern Canada and Siberia, North Sea, and arctic petroleum reserves), and shallower scale investigations into the dynamics if individual ice sheets and glaciers, as well as the identification of shallow groundwater systems and how they interact and are related to surface features (e.g., glaciers, lakes, permafrost zones).

Acknowledgements I thank the program committee of the 24th EM Induction Workshop for the opportunity to prepare this review. I would like to acknowledge those within the EM community who have provided source materials and figures from both published and unpublished research relevant to this review: P. Bedrosian, G. Boren, K. Key, J. Mikucki, J. Peacock, O. Ritter, K. Selway, M. Smirnov, J. Stodt, D. Uhlmann, and P. Wannamaker. Support for preparation of the review was provided by New Zealand Royal Society Marsden Fund award \# ASL-1301 and a Lumina Quaeruntur fellowship to G. Hill. Central Transantarctic work supported by National Science Foundation, Office of Polar Programs Award \# 0838914 and 1243559 and logistical support through the United States Antarctic Program; Mount Erebus work supported by New Zealand Royal Society Marsden award \# ASL-1301 and National Science Foundation Office of Polar Programs award \# 1443522, with logistical support provided by Antarctica New Zealand and the United States Antarctic Program. B. Fernandez is thanked for assistance in producing the polar projection maps. M. Smirnov is thanked for editorial handling, with comments from K. Selway and an anonymous reviewer improving the manuscript.

Open Access This article is distributed under the terms of the Creative Commons Attribution 4.0 International License (http://creativecommons.org/licenses/by/4.0/), which permits unrestricted use, distribution, and reproduction in any medium, provided you give appropriate credit to the original author(s) and the source, provide a link to the Creative Commons license, and indicate if changes were made.

\section{References}

Ablay GJ, Carroll MR, Palmer MR, Marti J, Sparks RSJ (1998) Basanite-phonolite lineages of the TeidePico Viejo volcanic complex, Tenerife, Canary Islands. J Petrol 39:905-937

Akasofu SI (1964) The development of the auroral substorm. Planet Space Sci 12(4):273-282. https://doi. org/10.1016/0032-0633(64)90151-5

Akasofu SI (1977) Physics of magnetospheric substorms. Reidel, Dorrecht, p 559

Akasofu SI (2015) Auroral substorms as an electrical discharge phenomenon. Prog Earth Planet Sci 2:1-21

Al-Kindi S, White N, Sinha M, England R, Tiley R (2003) Crustal trace of a hot convective sheet. Geology 31(3):207-210. https://doi.org/10.1130/0091-7613

Bamber JL, Riva REM, Vermeersen BLA, Le Brocq AM (2009) Reassessment of the potential sea-level rise from a collapse of the West Antarctic Ice Sheet. Science 324(5929):901-903

Banks RJ (1998) The effects of non-stationary noise on electromagnetic response estimates. Geophys J Int 135:553-563. https://doi.org/10.1046/j.1365-246x.1998.00661.x 
Barre M (1954) Propriétés Électriques du Blizzard. Résultats Scientifiques, No. S IV, 1, Expéditions Polaires Françaises, Terre Adélie, 1951-1952

Baumjohann W, Treumann RA (1997) Basic space plasma physics. Imperial College Press, London

Beblo M, Liebig V (1990) Magnetotelluric measurements in Antarctica. Phys Earth Planet Inter 60:89-99. https://doi.org/10.1016/0031-9201(90)90251-r

Bedrosian PA, Unsworth MJ, Egbert G (2002) Magnetotelluric imaging of the creeping segment of the San Andreas fault near Hollister. Geophys Res Lett 29:1-4

Bedrosian PA, Peacock J, Bowles-Martinez E, Schultz A, Hill GJ (2018) Crustal inheritance and topdown control on arc magmatism: Mount St. Helens in focus. Nat Geosci 11:865-870

Behrendt JD (1999) Crustal and lithospheric structure of the West Antarctic Rift system from geophysical investigations-a review. Global Planet Change 23:25-44

Beka TI (2016) Geoelectrical structures beneath Spitsbergen-Svalbard derived from magnetotelluric imaging. Doctoral dissertation - the Arctic University of Norway, Faculty of Science and Technology, Department of Physics and Technology

Beka TI, Smirnov M, Bergh SG, Birkelund Y (2015) The first magnetotelluric image of the lithosphericscale geological architecture in central Svalbard, Arctic Norway. Polar Res. 34:26766

Beka TI, Smirnov M, Birkelund Y, Senger K, Bergh SG (2016) Analysis and 3D inversion of magnetotelluric crooked profile data from central Svalbard for geothermal application. Tectonophysics 686:98-115

Beka TI, Bergh SG, Smirnov M, Birkelund Y (2017a) Magnetotelluric signatures of the complex tertiary fold-thrust belt and extensional fault architecture beneath Brøggerhalvøya, Svalbard. Polar Res 36(1):1409586. https://doi.org/10.1080/17518369.2017.1409586

Beka TI, Senger K, Autio UA, Smirnov M, Birkelund Y (2017b) Integrated electromagnetic data investigation of a Mesozoic $\mathrm{CO}_{2}$ storage target reservoir-cap-rock succession, Svalbard. J Appl Geophys 136:417-430

Bell RE (2008) The role of subglacial water in ice-sheet mass balance. Nat Geosci 1(5):297-304

Bentley CR (1973) Crustal structure of Antarctica. Tectonophysics 20:229-240

Bentley CR (1977) Electrical resistivity measurements on the Ross Ice Shelf. J Glaciol 18(78):15-35

Bentley CR (1991) Configuration and structure of the subglacial crust. In: Tingey RJ (ed) The geology of Antarctica. Clarendon, Oxford, pp 335-364

Bentley CR, Jezek KC, Blankenship DD, Lovell JS, Albert DG (1979) Geophysical investigation of the Dome C area, Antarctica. Antarct J USA 14(5):98-100

Ben-Zvi T, Wilcock WSD, Barclay A, Zandomeneghi D, Ibanez JM, Almedros J (2009) The P wave velocity structure of Deception Island, Antarctica, from two dimensional seismic tomography. J Volcanol Geotherm Res 180:67-80

Bergh SG, Grogan P (2003) Tertiary structure of the Sorkapp-Hornsund region, south Spitsbergen, and implications for the offshore southern extension of the fold-thrust belt. Norw J Geol 83:43-60

Bezada MJ, Humphreys ED, Davila JM, Carbonell R, Harnafi M, Palomeras I, Levander A (2014) Piecewise delamination of Moroccan lithosphere from beneath the Atlas Mountains. Geochem Geophys Geosyst 15:975-985. https://doi.org/10.1002/2013gc005059

Blankenship DD, Morse D, Finn CA, Bell R, Peters ME, Kempf SD, Hodge SM, Studinger M, Behrendt JC, Brozena JM (2001) Geologic controls on the initiation of rapid basal motion for West Antarctic ice streams: a geophysical perspective including new airborne radar sounding and laser altimetry results. In: Alley RB, Bindschadler RA (eds) The west Antarctic ice sheet: behavior and environment, volume 77: Antarctic Research Series. American Geophysical Union, Washington, pp 105-121

Boerner DE, Kurtz RD, Craven JA (1996) Electrical conductivity and Paleo-Proterozoic foredeeps. J Geophys Res Atmos 101(B6):13775-13791. https://doi.org/10.1029/96jb00171

Booker J, Favetto A, Pomposiello C (2004) Low electrical resistivity associated with plunging of the Nazca flat slab beneath Argentina. Nature 429:399-403

Boren G (2018) pers comm., University of Adelaide, Department of Earth Sciences goran.boren@adelaide.edu.au

Boteler DH, Pirjola RJ (1998) The complex-image method for calculating the magnetic and electric fields at the surface of the Earth by the auroral electrojet. Geophys J Int 132:31-40

Boteler DH, Willink R (1984) Magnetotelluric/VLF studies. N Z Antarct Rec 5(3):47

Brasse H, Kreutzmann A, Cerv V, Ernst T, Jankowski J, Jozwiak W, Neska A, Pedersen LB, Smirnov M, Schwarz G, Sokolova E, Varentsov IM, Hoffmann N, Palshin N, Korja T (2006) Probing electrical conductivity of the Trans-European Suture Zone. EOS Trans Am Geophys Union 87(29):281

Brenn GR, Hansen SE, Park Y (2017) Variable thermal loading and flexural uplift along the Transantarctic Mountains, Antarctica. Geology 45:463-466. https://doi.org/10.1130/g38784.1 
Briggs MA, Campbell S, Nolan J, Walvoord MA, Ntarlagiannis D, Day-Lewis FD, Lane JW (2016) Surface geophysical methods for characterising frozen ground in transitional permafrost landscapes. Permafr Periglac Process. https://doi.org/10.1002/ppp.1893

Bubnov VP, Yakovlev GA, Aleksanova ED, Yakovlev DV, Berdichevisky MN, Pushkarev PY (2007) Magnetotelluric studies of the East-European Craton and Adjacent Regions. Acta Geophys 55(2):154-168. https://doi.org/10.2478/s11600-006-0034-7

Byerlee J (1993) Model for episodic flow of high-pressure water in fault zones before earthquakes. Geology 21:303-306

Campbell S, Affleck RT, Sinclair S (2018) Ground-penetrating radar studies of permafrost, periglacial, and near-surface geology at McMurdo Station, Antarctica. Cold Reg Sci Technol 148:38-49. https ://doi.org/10.1016/j.coldregions.2017.12.008

Cande SC, Stock JM, Muller RD, Ishihara T (2000) Cenozoic motion between East and West Antarctica. Nature 404:145-150

Chakrabarti R, Basu AR, Tedesco D, Santo A (2009) Isotopic and geochemical study of the Nyiragongo and Nyamulagira volcanic in the western side of the East African rift System. Chem Geol 259:273-289

Chave AD, Thompson DJ (1989) Some comments on magnetotelluric response function estimation. J Geophys Res 94:14215-14225

Cherevatova M, Smirnov MY, Jones AG, Pedersen LB, MaSca Working Group (2015a) Magnetotelluric array data analysis from north-west Fennoscandia. Tectonophysics 653:1-19

Cherevatova M, Smirnov MY, Korja T, Pedersen LB, Ebbing J, Gradmann S, Becken M, MaSca Working Group (2015b) Electrical conductivity structure of north-west Fennoscandia from threedimensional inversion of magnetotelluric data. Tectonophysics 653:20-32

Clarke TS, Burkholder PD, Smithson SB, Bentley CR (1997) Optimum seismic shooting and recording parameters and a preliminary crustal model for the Byrd Subglacial Basin, Antarctica. In: Ricci CA (ed) The Antarctic region: geological evolution and processes. Terra Antartica Publications, Sienna, pp 485-493

Collier AB, Lichtenberger J, Clilverd MA, Rodger CJ, Steinbach P (2011) Source region for whistlers detected at Rothera, Antarctica. J Geophys Res 116:A03219. https://doi.org/10.1029/2010ja0161 97

Constable C (2016) Earth's electromagnetic environment. Surv Geophys 37:27-45. https://doi. org/10.1007/s10712-015-9351-1

Cornelis WM (2006) Hydroclimatology of wind erosion in arid and semiarid environments. In: D’Odorico P, Porporato A (eds) Dryland ecohydrology. Springer, The Netherlands, pp 141-159

Dalziel IWD, Lawver LA (2001) The lithospheric setting of the West Antarctic ice sheet. In: Alley RB, Bindschadler RA (eds) The West Antarctic ice sheet: behavior and environment, volume 77: Antarctic research series. American Geophysical Union, Washington, pp 29-44

Davey FJ, Brancolini G (1995) The late Mesozoic and Cenozoic structural setting of the Ross Sea region. In: Cooper AK, Barker PF, Brancolini G (eds) Geology and seismic stratigraphy of the Antarctic margin, volume 68: Antarctic Research series. AGU, Washington, pp 167-182

Doran PT, Priscu JC, Lyons WB, Walsh J (2002) Antarctic climate cooling and terrestrial ecosystem response. Nature 415:517-520. https://doi.org/10.1038/nature710

Dowdeswell JA (2006) The Greenland ice sheet and global sea-level rise. Science 311:963-964. https:// doi.org/10.1126/science. 1124190

Dugan HA, Doran PT, Tulaczyk S, Mikucki JA, Arcone SA, Auken E, Schamper C, Virginia R (2015) Subsurface imaging reveals a confined aquifer beneath an ice-sealed Antarctic lake. Geophys Res Lett 42(1):96-103. https://doi.org/10.1002/2014g1062431

Eberhart-Phillips D, Haeussler PJ, Freymueller JT, Frankel AD, Rubin CM, Craw P, Ratchkovski NA, Anderson G, Carver GA, Crone AJ, Dawson TE, Fletcher H, Hansen R, Harp EL, Harris RA, Hill DP, Hreinsdóttir S, Jibson RW, Jones LM, Kayen R, Keefer DK, Larsen CF, Moran SC, Personius SF, Plafker G, Sherrod B, Sieh K, Sitar N, Wallace WK (2003) The 2002 Denali fault earthquake, Alaska: a large magnitude, slip-partitioned event. Science 300:1113-1118

Egbert GD (1997) Robust multiple-station MT data processing. Geophys J Int 130:475-496

Egbert GD (2002) Processing and interpretation of electromagnetic induction array data. Surv Geophys 23:207-249. https://doi.org/10.1023/a:1015012821040

Engels M, Korja T, BEAR working group (2002) Multisheet modelling of the electrical conductivity structure of the Fennoscandian Shield. Earth Planets Space 54:559-593

Evans S, Jones AG, Spratt J, Katsube J (2005) Central Baffin electromagnetic experiment (CBEX): mapping the North American Central Plains (NACP) conductivity anomaly in the Canadian arctic. Phys Earth Planet Inter 150:107-122. https://doi.org/10.1016/j.pepi.2004.08.032 
Fahnestock M, Abdalati W, Joughin I, Brozena J, Gogineni P (2001) High geothermal heat flow, basal melt, and the origin of the rapid ice flow in central Greenland. Science 294(5550):2338-2342

Faleide JI, Tsikalas F, Breivik AJ, Mjelde R, Ritzmann O, Engen O, Wilson J, Eldholm O (2008) Structure and evolution of the continental margin off Norway and the Barents Sea. Episodes 31:82

Fisher MA, Nokleberg WJ, Ratchkovski NA, Pellerin L, Glen JM, Brocher TM, Booker J (2004) Geophysical investigation of the Denali Fault and Alaska Range orogeny within the aftershock of the October-November 2002, M = 7.9 Denali fault earthquake. Geology 32(3):269-272. https://doi. org/10.1130/g20127.1

Fitzgerald P (2002) Tectonics and landscape evolution of the Antarctic plate since the breakup of Gondwana, with an emphasis on the West Antarctic Rift System and the Transantarctic Mountains. R Soc N Z Bull 35:453-469

Fitzgerald PG, Stump E (1997) Cretaceous and Cenozoic episodic denudation of the Transantarctic Mountains, Antarctica: new constraints from apatite fission track thermochronology in the Scott Glacier region. J Geophys Res 102:7747-7765

Fitzgerald P, Sandiford M, Barrett P, Gleadow A (1986) Asymmetric extension associated with uplift and subsidence in the Transantarctic Mountains and Ross Embayment. Earth Planet Sci Lett 81:67-78

Foley N, Tulaczyk S, Auken E, Schamper C, Dugan H, Mikiucki J, Virginia R, Doran P (2016) Helicopterborne transient electromagnetics in high-latitude environments: an application in the McMurdo Dry Valleys, Antarctica. Geophysics 81(1):WA87-WA99

Galindo-Zaldívar J, Gamboa L, Maladonado A, Nakao S, Bochu Y (2004) Tectonic development of the Bransfield basin and its prolongation to the South Scotia Ridge, northern Antarctic Peninsula. Mar Geol 206:267-282

Garcia X, Chave AD, Jones AG (1997) Robust processing of magnetotelluric data from the auroral zone. J. Geomag Geoelectr 49:1451-1468

Giggenbach WF, Kyle PR, Lyon GL (1973) Present volcanic activity on Mount Erebus, Ross Island, Antarctica. Geology 1:135-136

Glen J, Schmidt J, Morin R (2007) Gravity and magnetic character of south-central Alaska: constraints on geologic and tectonic interpretations, and implications for mineral exploration. In: Ridgway KD et al (eds) Tectonic growth of a collisional continental margin: crustal evolution of Southern Alaska. Special Papers Geological Society of America, vol 431, pp 593-622

Golledge NR, Kowalewski DE, Naish TR, Levy RH, Fogwill CJ, Gasson EGW (2015) The multi-millennial Antarctic commitment to future sea-level rise. Nature 526:421-425. https://doi.org/10.1038/natur e15706

Goodge JW, Fanning CM, Norman MD, Bennett VC (2012) Temporal, isotopic and spatial relations of Early Paleozoic Gondwana-Margin Arc Magmatism, Central Transantarctic Mountains, Antarctica. J Petrol 53(10):2027-2065. https://doi.org/10.1093/petrology/egs043

Gordon M, Taylor PA (2009) The electric field during blowing snow events. Bound Layer Metrol 130:97115. https://doi.org/10.1007/s10546-008-9333-7

Greischar L, Bentley C (1980) Isostatic equilibrium grounding line between the West Antarctic inland ice sheet and the Ross Ice Shelf. Nature 283:651-654

Griffiths DJ (1981) Introduction to electrodynamics, 4th edn. Pearson, Cambridge University Press, p 599

Hakkinen L, Pirjola R (1986) Calculation of electric and magnetic fields due to an electrojet current system above a layered earth. Geophysica 22:31-44

Hansen SE, Graw JH, Kenyon LM, Nyblade AA, Wiens DA, Aster RC, Huerta AD, Anandakrishnan S, Wilson T (2014) Imaging the Antarctic mantle using adaptively parameterized P-wave tomography: evidence for heterogeneous structure beneath West Antarctica. Earth Planet Sci Lett 408:66-78

Hautot S, Tarits P (2016) Joint MT-gravity inversion in a complex geological environment: example of western Greenland margin. In: Poster at the 23rd electromagnetic induction workshop

Heeszel DS, Wiens DA, Nyblade AA, Hansen SE, Kanao M, An M, Zhao Y (2013) Rayleigh wave constraints on the structure and tectonic history of the Gamburtsev Subglacial Mountains, East Antarctica. J Geophys Res 118:2138-2153

Heincke B, Chen J, Riisager P, Kolb J, Jørgensen AF (2015) 2-D magnetotelluric experiment to investigate the Nassugtoqidian orogeny in South-East Greenland. In: EGU general assembly conference abstracts, vol 17, p 6720

Heise W, Caldwell TG, Hill GJ, Bennie SL, Wallin E, Bertrand EA (2012) Magnetotelluric imaging of fluid processes at the subduction interface of the Hikurangi Margin, New Zealand. Geophys Res Lett 39:L04308. https://doi.org/10.1029/2011g1050150

Henriksen E, Ryseth A, Larssen G, Heide T, Rønning K, Sollid K, Stoupakova A (2011) Tectonostratigraphy of the greater Barents Sea: implications for petroleum systems. Geol Soc Lond Mem 35:163-195 
Henry PSH (1953) The role of asymmetric rubbing in the generation of static electricity. Br J Appl Phys Suppl 2:S31-S36

Hessler VP, Jacobs J (1966) A telluric current experiment on the Antarctic ice cap. Nature 210:190-191. https://doi.org/10.1038/210190a0

Hill GJ, Bibby HM, Ogawa Y, Wallin EL, Bennie SL, Caldwell TG, Keys H, Bertrand EA, Heise W (2015) Structure of the Tongariro Volcanic system: insights from magnetotelluric imaging. Earth Planet Sci Lett. https://doi.org/10.1016/j.eps1.2015.10.003

Hill G, Wannamaker P, Stodt J, Unsworth J, Maris V, Bedrosian P, Wallin E, Kordy M, Ogawa Y, Kyle P, Uhlmann D (2019) Imaging structural controls on the Erebus volcano magmatic system, Antarctica using the magnetotelluric method. In: Invited keynote lecture for theme: continental evolution of Antarctica. Antarctic volcanism and magmatism; past, present, and future. Abstract: A066. XIII international symposium on antarctic earth sciences (ISAES), Incheon, Republic of Korea, 22-26 July 2019

Hochstein M (1967) Electrical resistivity measurements on ice sheets. J Glaciol 6(47):623-633

Hole MJ, LeMasurier WE (1994) Tectonic controls on the geochemical composition of Cenozoic, mafic alkaline volcanic rocks from West Antarctica. Contrib Mineral Petrol 117:187-202

Huerta A (2007) Lithospheric Structure across the transantarctic mountains constrained by an analysis of gravity and thermal structure. USGS open file report, 2007-1047

Huerta A, Harry D (2007) The transition from diffuse to focused extension: modeled evolution of the West Antarctic Rift system. Earth Planet Sci Lett 255:133-147

Ingeman-Nielsen $\mathrm{T}$ (2006) The effect of electrode contact resistance and capacitive coupling on complex resistivity measurements. In: SEG annual meeting abstracts, pp 1376-1380

Ivins ER (2009) Ice sheet stability and sea level. Science 2009(324):888-889

Jones AG (1983) The electrical structure of the lithosphere and asthenosphere beneath the Fennoscandian Shield. J Geomagn Geoelectr 35:811-827

Jones AG, Spratt J (2002) A simple method for deriving the uniform field MT responses in auroral zones. Earth Planets Space 54(5):443-450

Jones A, Chave A, Egbert G, Auld D, Bahr K (1989) A comparison of techniques for magnetotelluric response function estimation. J Geophys Res 94:201-214

Jones AG, Ledo J, Ferguson IJ, Farquharson C, Garcia X, Grant N, McNeice GW, Roberts B, Spratt J, Wennberg G, Wolynec L, Wu X (2005) The electrical resistivity structure of Archean to Tertiary lithosphere along $3200 \mathrm{~km}$ of SNORCLE profiles, northwestern Canada. Can J Earth Sci 42(6):1257-1275

Jordan TA, Martin C, Ferraccioli F, Matsuoka K, Corr H, Forsberg R, Olesen A, Siegert M (2018a) Anomalously high geothermal flux near the South Pole. Sci Rep 8:16785. https://doi.org/10.1038/s4159 8-018-35182-0

Jordan TM, Williams CN, Schroeder DM, Martos YM, Cooper MA, Siegert MJ, Paden JD, Huybrechts P, Bamber JL (2018b) A constraint upon the basal water distribution and thermal state of the Greenland Ice Sheet from radar bed echoes. Cryosphere 12:2831-2854. https://doi.org/10.5194/tc-12-2831-2018

Joughin I, Alley RB (2011) Stability of the West Antarctic ice sheet in a warming world. Nat Geosci 4(8):506-513

Kaikkonen P, Vanyan LL, Hjelt SE, Shilovsky AP, Pajunpaa K, Shilovsky PP (1983) A preliminary geoelectric model of the Karelian megablock of the Baltic Shield. Phys Earth Planet Inter 32:301-305

Kamb B (1987) Glacier surge mechanism based on linked cavity configuration of the basal water conduit system. J Geophys Res 92(B9):9083-9100. https://doi.org/10.1029/jb092ib09p09083

Karlstrom KE, Ahall KI, Harlan SS, Williams ML, McLelland J, Geissman JW (2001) Long-lived (1.8$1.0 \mathrm{Ga}$ ) convergent orogen in southern Laurentia, its extensions to Australia and Baltica, and implications for refining Rodinia. Precambrian Res 111:5-30

Key K (2019) pers comm., Columbia University, Lamont Doherty Earth Observatory, kkey@1deo.columbia. edu

Key K, Siegfried MR (2017) The feasibility of imaging subglacial hydrology beneath ice streams with ground-based electromagnetics. J Glaciol 63(241):755-771. https://doi.org/10.1017/jog.2017.36

Khutorskoi M, Leonov YG, Ermakov A, Akhmedzyanov V (2009) Abnormal heat flow and the trough's nature in the northern Svalbard plate. Dokl Earth Sci 424:29-35

Kordy M, Wannamaker P, Maris V, Cherkaev E, Hill G (2016a) Three-dimensional magnetotelluric inversion using deformed hexahedral edge finite elements and direct solvers parallelized on SMP computers, part I: forward problem and parameter jacobians. Geophys J Int 204:74-93

Kordy M, Wannamaker P, Maris V, Cherkaev E, Hill G (2016b) Three-dimensional magnetotelluric inversion using deformed hexahedral edge finite elements and direct solvers parallelized on SMP computers, part II: direct data-space inverse solution. Geophys J Int 204:94-110 
Korepanov V, Maksymchuk V, Ladanivsky B (2006) Earth crust deep structure and dynamics study at the "Verandsky Station" region by geoelectromagnetic methods-present state and perspectives. Terra Antarct Rep 12:155-166

Korja T (2007) How is the European lithosphere imaged by magnetotellurics? Surv Geophys 28:239-272. https://doi.org/10.1007/s10712-007-9024-9

Korja T, Hjelt SE (1993) Electromagnetic studies in Fennoscandian Shield-electrical conductivity of Precambrian crust. Phys Earth Planet Inter 81:107-138

Korja T, Koivukoski K (1994) Crustal conductors along the SVEKA profile in the Fennoscandian (Baltic) Shield, Finland. Geophys J Int 116(1):173-197. https://doi.org/10.1111/j.1365-246x.1994.tb02135.x

Korja T, Engels M, Zhamaletdinov A, Kovtun A, Palshin N, Tokarev A, Smirnov M, Asming V, Vanyan L, Vardaniants I, Bear WG (2002) Crustal conductivity in Fennoscandia-a compilation of a database on crustal conductance in the Fennoscandian Shield. Earth Planets Space 54:535-558

Korja T, Smirnov M, Pedersen L, Gharibi M (2008) Structure of the Central Scandinavian Caledonides and the underlying Precambrian basement, new constraints from magnetotellurics. Geophys J Int 175:55-69

Kulessa B (2007) A critical review of the low-frequency electrical properties of ice sheets and glaciers. J Environ Eng Geophys 12(1):23-36

Kyle PR, Moore JA, Thirlwall MF (1992) Petrologic evolution of anorthoclase phonolite lavas at Mount Erebus, Ross Island, Antarctica. J Petrol 33:849-875

Lahti I, Korja T, Kaikkonen P, Vaittinen K, BEAR, W.G. (2005) Decomposition analysis of the BEAR magnetotelluric data: implications for the upper mantle conductivity in the Fennoscandian Shield. Geophys J Int 163:900-914

Latham J (1964) The electrification of snowstorms and sandstorms. Q J R Meteorol Soc 90:91-95

Latham J, Stow CD (1967) A laboratory investigation of the electrification of sandstorms. Q J R Meteorol Soc 93(395):55-68

Lauritsen NLB, Olsen N, Junge A, Matzka J (2016) Magnetotelluric investigation in West Greenland-considering the polar electrojet, ocean and fjords. Kgs. Lyngby: Technical University of Denmark (DTU)

Lawrence JF, Wiens DA, Nyblade AA, Anandakrishnan S, Shore PJ, Voigt D (2006) Crust and upper mantle structure of the Transantarctic Mountains and surrounding regions from receiver functions, surface waves, and gravity: implications for uplift models. Geochem Geophys Geosyst 7:23. https://doi. org/10.1029/2006gc001282

Lawver LA, Gahagan LM, Dalziel IWD (1998) A tight fit Early Mesozoic Gondwana, a plate reconstruction perspective. In: Memoirs of the National Institute of Polar Research: international symposium on the origin and evolution of continents. National Institute of Polar Research, Tokyo, pp 214-229

LeMasurier WE, Landis CA (1996) Mantle-plume activity recorded by low-relief erosion surfaces in West Antarctica and New Zealand. Geol Soc Am Bull 108:1450-1466

LeMasurier WE, Rex DC (1991) The Marie Byrd Land volcanic province and its relation to the Cainozoic West Antarctic rift system. In: Tingey RJ (ed) The geology of Antarctica. Clarendon, Oxford, pp 249-284

Levy R, Harwood D, Florindo F, Sangiorgi F, Tripati R, von Eynatten H, Gasson E, Kuhn G, Tripati A, DeConto R, Fielding C, Field B, Golledge N, McKay R, Naish TR, Dunbar G, SMS Science Team (2016) Antarctic ice sheet sensitivity to atmospheric $\mathrm{CO}_{2}$ variations in the early to mid-Miocene. Proc Natl Acad Sci 113:3453-3458. https://doi.org/10.1073/pnas.1516030113

Long KR, Van Gosen BS, Foley NK, Cordier D (2010) The principal rare earth elements deposits of the United States-a summary of domestic deposits and a global perspective. Scientific Investigations Report. United States Geological Survey and United States Department of the Interior, Virginia, p 104

MacGregor JA, Fahnestock MA, Catania GA, Paden JD, Gogineni SP, Young SK, Rybarski SC, Mabrey AN, Wagman BM, Morlighem M (2015) Radiostratigraphy and age structure of the Greenland Ice Sheet. J Geophys Res Earth Surf 120:212-241. https://doi.org/10.1002/2014jf003215

Maclennan J, Lovell B (2002) Control of regional sea level by surface uplift and subsidence caused by magmatic underplating of Earth's crust. Geology 30:675-678

Mareschal M (1986) Modelling of natural sources of magnetospheric origin in the interpretation of regional induction studies: a review. Surv Geophys 8:261-300

Marti J, Vila J, Rey J (1996) Deception Island (Bransfield Strait, Antarctica) an example of a volcanic caldera developed by extensional tectonic. In: McGuire WC, Jones AP, Neuberg J (eds) Volcano instabilities on the Earth and other planets. Geological Society of London Special Publications, vol 110, pp 253-265

Mellor M (1965) Blowing snow, CRREL monograph, part III, Section A3c, US Army Corps of Engineers, Cold Regions Research and Engineering Laboratory, Hanover, NH, USA, p 79 
Middleton RT (2000) Hydrogeological characterisation using high resolution electrical resistivity and radar tomographic imaging. Ph.D. Thesis, Lancaster University, Lancaster

Mikucki JA, Auken E, Tulaczyk S, Virginia RA, Schamper C, Sorensen KI, Doran PT, Dugan H, Foley N (2015) Deep groundwater and potential subsurface habitats beneath an Antarctic dry valley. Nat Commun 6:6831. https://doi.org/10.1038/ncomms7831

Miller S, Fitzgerald P, Baldwin S (2010) Cenozoic range-front faulting and development of the Transantarctic Mountains near Cape Surprise, Antarctica: thermochronologic and geomorphologic constraints. Tectonics 29:21

Moussallam Y, Oppenheimer C, Scaillet B, Kyle P (2013) Experimental phase equilibrium constraints on the phonolite magmatic system of Erebus volcano, Antarctica. J Petrol 54:1285-1307. https:// doi.org/10.1093/petrology/egt012

Murthy DN, Veeraswamy K, Harinarayana T, Singh UK, Santosh M (2013) Electrical structure beneath Schirmacher Oasis, East Antarctica: a magnetotelluric study. Polar Res 32:17309. https://doi. org/10.3402/polar.v32i0.17309

Naish T, Zwartz D (2012) Looking back to the future. Nat Clim Change 2:317-318. https://doi. org/10.1038/nclimate1504

Nonnotte P, Benoit M, Le Gall B, Hémond C, Rolet J, Cotton J, Brunet P, Makoba E (2011) Petrology and geochemistry of alkaline lava series, Kilimanjaro, Tanzania: new constraints on petrogenetic processes. In: Beccaluva LG, Wilson M (eds) Volcanism and evolution of the African lithosphere: Geological Society of America Special Paper, vol 478, pp 127-158

Olsen N (2007) Natural sources for electromagnetic induction studies. In: Gubbins D, Herrero-Bervera E (eds) Encyclopedia of geomagnetism and paleomagnetism. Springer, Berlin, pp 696-700

Olsen N, Stolle C (2017) Magnetic signatures of ionospheric and magnetospheric current systems during geomagnetic quiet conditions - an overview. Space Sci Rev 206(1-4):5-25

Oppenheimer C, Kyle PR (2008) Probing the magma plumbing of Erebus volcano, Antarctica, by openpath FTIR spectroscopy of gas emissions. J Volcanol Geotherm Res 177:743-754

Osipova IL, Hjelt SE, Vanyan LL (1989) Source field problems in northern parts of the Baltic Shield. Phys Earth Planet Inter 53:337-342

Pajunpaa K (1987) Conductivity anomalies in the Baltic Shield in Finland. Geophys J R Astron Soc 91:657-666

Parkinson WD (1962) The influence of continents and oceans on geomagnetic variations. Geophys J R Astron Soc 6:441-449

Pascal C, Balling N, Barrere C, Davidsen B, Ebbing J, Elvebakk H, Mesli M, Roberts D, Slagstad T, Willemoes-Wissing B (2011) HeatBar final report 2010, basement heat generation and heat flow in the western Barents Sea-importance for hydrocarbon systems. Technical Report, Geological Survey of Norway

Peacock JR, Selway K (2016) Magnetotelluric investigation of the Vestfold Hills and Rauer Group, East Antarctica. J Geophys Res Solid Earth 121:4. https://doi.org/10.1002/2015jb012677

Pedrera A, Ruiz-Constan A, Heredia N, Galindo-Zaldivar J, Bohoyo F, Marin-Lechado C, Ruanao P, Somoza L (2012) The fracture system and the melt emplacement beneath the Deception Island active volcano, South Shetland Islands, Antarctica. Antarct Sci 24(2):173-182. https://doi. org/10.1017/S0954102011000794

Pirjola R (1992) On magnetotelluric source effects caused by an auroral electrojet system. Radio Sci 4:463-468. https://doi.org/10.1029/92rs00852

Pirjola R, Viljanen A (1998) Complex image method for calculating electric and magnetic fields produced by an auroral electrojet of a finite length. Ann Geophys 16:1434-1444

Potemra T (1991) Magnetospheric substorms. American Geophysical Union, Washington, p 488

Pritchard HD, Vaughan DG (2007) Widespread acceleration of tidewater glaciers on the Antarctic Peninsula. J Geophys Res Earth Surf 112(F3):29

Radok U (1968) Deposition and erosion of snow by wind. US Army Cold Regions Research and Engineering Laboratory. Research Report vol 230, p 23

Rasmussen TM, Roberts RG, Pedersen LB (1987) Magnetotellurics along the Fennoscandian long range profile. Geophys J R Astron Soc 89:799-820

Reynolds JM, Paren JG (1980) Recrystallisation and electrical behaviour of glacier ice. Nature 283:63-64

Reynolds JM, Paren JG (1984) Electrical resistivity of ice from the Antarctic Peninsula. Antarct J Glaciol 30(106):289-295

Ritter O (2018) pers comm., GFZ German Research Centre for Geosciences, Section 2.7 Near-surface Geophysics, Oliver.Ritter@gfz-potsdam.de 
Ritter O, Kuleassa B (2018) pers comm., GFZ German Research Centre for Geosciences, Section 2.7 Near-surface Geophysics, Oliver.Ritter@gfz-potsdam.de; Department of Geography, University of Swansea, b.kulessa@swansea.ac.uk

Robinson C (1956) Geology of devils tower national monument, Wyoming. US Geol Surv Bull 1021(1):13

Rostoker G (1996) Phenomenology and physics of magnetospheric substorms. J Geophys Res 101:12955-12973

Ruotoistenmäki T, Lehtimäki J (1997) Estimation of permafrost thickness using ground geophysical measurements, and its usage for defining vertical temperature variations in continental ice and underlying bedrock. J Glaciol 43(1):359-364

Savelyev SA, Gordon M, Hanesiak J, Papakourioki T, Taylor PA (2006) Blowing snow studies in CASES (Canadian Arctic Shelf Exchange Study) 2003-04. Hydrol Proc 20(4):817-827

Scaillet B, Pichavant M, Cioni R (2008) Upward migration Vesuvius magma chamber over the past 20000 years. Nature 455:216-219

Schmidt DS, Dent JD (1993) A theoretical prediction of the effects of electrostatic forces on saltating snow particles. Ann Glaciol 18:234-238

Schmidt DS, Dent JD (1994) Measurements of the electric field gradient in a Blizzard. In: Proceedings of international snow science workshop, Oct. 30-Nov. 3, 1994, Snowbird, UT, USA, pp 197-202

Schmidt DS, Schmidt RA, Dent JD (1998) Electrostatic force on saltating sand. J Geophys Res 103(D8):8997-9001

Schmidt DS, Schmidt RA, Dent JD (1999) Electrostatic force in blowing snow. Bound Layer Meteorol 93:29-45

Schultz A, Imamura N, Bonner LR, Cosgrove RB (2016) Frequency domain and full waveform time domain inversion of ground based magnetometer, electrometer and incoherent scattering radar arrays to image strongly heterogenous 3-D Earth structure, ionospheric structure, and to predict the intensity of GICs in the power grid. Abstract GP23D-03, AGU Fall Meeting San Francisco, CA, 12-16 December 2016

Self S, Blake S (2008) Consequences of Explosive supereruptions. Elements 4:41-46

Self S, Gertisser R, Thordarson T, Rampino MR, Wolff JA (2004) Magma volume, volatile emissions, and stratospheric aerosols from the 1815 eruption of Tambora. Geophys Res Lett 31:L20608

Selway K (2019) pers comm., Macquarie University, Department of Earth and Planetary Sciences, kate. selway@mq.edu.au

Selway K, Conrad C (2018) Using MT to constrain Greenland's glacial isostatic adjustment and ice loss. In: Abstract S4.1-P489, 24th electromagnetic induction of the earth workshop, Helsingor, Denmark, 13-20 August 2018

Shabtaie S, Bentley CR (1994) Electrical resistivity measurements on ice stream B, Antarctica. Ann Glaciol 20(1):129-136. https://doi.org/10.3189/172756494794587465

Shabtaie S, Bentley CR (1995) Electrical resistivity sounding of the East Antarctic ice sheet. J Geophys Res 100:1933-1954. https://doi.org/10.1029/94jb02620

Shabtaie S, Bentley CR, Blankenship DD, Lovell JS, Gassett RM (1980) Dome c geophysical survey, 1979-80. Antarct J USA 15(5):2-5

Shen W, Wiens DA, Stern T, Anandakrishnan S, Aster RC, Dalziel I, Hansen S, Heeszel DS, Huerta A, Nyblade A, Wilson TJ, Winberry P (2017) Seismic evidence for lithospheric foundering beneath the southern Transantarctic Mountains, Antarctica. Geology 46:71-74. https://doi.org/10.1130/ g39555.1

Shen W, Wiens DA, Anandakrishnan S, Aster RC, Gerstoft P, Bromirski PD, Hansen SE, Dalziel IWD, Heeszel DS, Huerta AD, Nyblade AA, Stephen R, Wilson TJ, Winberry JP (2018) The crust and upper mantle structure of central and West Antarctica from Bayesian inversion of Rayleigh wave and receiver functions. J Geophys Res Solid Earth 123:7824-7849. https://doi.org/10.1029/2017jb015346

Siegert MJ (1999) On the origin, nature and uses of Antarctic ice sheet radio-echo layering. Prog Phys Geogr 23(2):159-179

Siegert MJ (2000) Antarctic subglacial lakes. Earth Sci Rev 50:29-50

Siegert MJ, Kulessa B, Bougamont M, Christoffersen P, Key K, Andersen KR, Booth AD, Smith AM (2018) Antarctic subglacial groundwater: a concept paper in its measurement and potential influence on ice flow. In: Siegert MJ, Jamieson SSR, White DA (eds) Exploration of subsurface Antarctica: Uncovering past changes and modern processes. Geological Society London Special Publications 461, pp 197-213. https://doi.org/10.1144/sp461.8

Simpson GC (1919) British Antarctic expedition, pp 1910-1913, vol 1. Thacker, Spink and Co. 326 pp

Slagstad T, Balling N, Elvebakk H, Midttømme K, Olesen O, Olsen L, Pascal C (2009) Heat-flow measurements in Late Palaeoproterozoic to Permian geological provinces in south and central Norway 
and a new heat-flow map of Fennoscandia and the Norwegian-Greenland Sea. Tectonophysics 473:341-361. https://doi.org/10.1016/j.tecto.2009.03.007

Smellie JL (2001) Lithostratigraphy and volcanic evolution of Deception Island, South Shetland Islands. Antarct Sci 13:188-209

Smirnov MY (2003) Magnetotelluric data processing with a robust statistical procedure having a high breakdown point. Geophys J Int 152:1-7

Smirnov MY (2019) pers comm., Lulea University of Technology, Department of Civil, Environmental and Natural Resources engineering, maxim.smirnov@1tu.se

Smirnov MY, Egbert GD (2012) Robust principal component analysis of electromagnetic arrays with missing data. Geophys J Int 190:1423-1438

Sokolova EY, Varentsov IM, Bear WG (2007) Deep array electromagnetic sounding on the Baltic Shield: external excitation model and implications for upper mantle conductivity studies. Tectonophysics 445:3-25

Sørensen KI, Auken E (2004) SkyTEM-A new high-resolution helicopter transient electromagnetic system. Explor Geophys 35:191-199

Spratt JE, Skulski T, Craven JA, Jones AG, Snyder DB, Kiyan D (2014) Magnetotelluric investigations of the lithosphere beneath the central Rae craton, mainland Nunavut, Canada. J Geophys Res Solid Earth 119:2415-2439. https://doi.org/10.1002/2013jb010221

Stern T, ten Brink U (1989) Flexural uplift of the Transantarctic Mountains. J Geophys Res 94:10315-10330

Stodt JA (2005) Numeric resources buffer amplifier user manual, 15 pp

Stodt JA (2018) pers comm., Numeric Resources LLC, jstodt@ numericresources.com

Storey BC (1996) Microplates and mantle plumes in Antarctica. Terra Antarct 3(2):91-102

Storey BC, Alabaster T (1991) Tectonomagmatic controls on Gondwana break-up models: evidence from the proto-Pacific margin of Antarctica. Tectonics 10:1274-1288

Storey BC, Leat PT, Weaver SD, Pankhurst RJ, Bradshaw JD, Kelley S (1999) Mantle plumes and Antarctica-New Zealand rifting: evidence from mid-Cretaceous mafic dykes. J Geol Soc Lond 156(4):659-671

Stump E (2011) The roof at the bottom of the world: discovering the Transantarctic Mountains. Yale University Press, New Haven, p 272

ten Brink U, Hackney R, Bannister S, Stern T, Makovsky Y (1997) Uplift of the trans Antarctic Mountains and the bedrock beneath the East Antarctic ice sheet. J Geophys Res 102:27603-27621

Thompson DJ, Chave AD (1991) Jackknifed error estimates for spectra, coherences, and transfer functions. In: Haykin S (ed) Advances in spectrum analysis and array processing. Prentice Hall, Englewood Cliffs, pp 58-113

Unsworth M, Bedrosian P, Eisel M, Egbert G, Siripunvaraporn W (2000) Along strike variations in the electrical structure of the San Andreas fault at Parkfield, California. Geophys Res Lett 27:3021-3024

Unsworth MJ, Jones AG, Wei W, Marquis G, Gokarn SG, Spratt JE (2005) Crustal rheology of the Himalaya and southern Tibet inferred from magnetotelluric data. Nature 438:78-81

Vagnes E, Amundsen HEF (1993) Late Cenozoic uplift and volcanism on Spitsbergen: caused by mantle convection? Geology 21:251-254

van der Beek P, Cloetingh S, Andriessen P (1994) Mechanisms of extensional basin formation and vertical motions at rift flanks: constraints from tectonic modeling and fission-track thermochronology. Earth Planet Sci Lett 121:417-433

van Wijk JW, Lawrence JF, Driscoll NW (2008) Formation of the Transantarctic Mountains related to extension of the West Antarctic rift system. Tectonophysics 458:117-126

Varentsov IM, Engels M, Korja T, Smirnov MY, BEAR working group (2002) A generalized geoelectric model of Fennoscandia: a challenging database for long period 3D modelling studies within the Baltic Electromagnetic Array Research (BEAR) project, Izvestya. Phys Solid Earth 38(10):855-896

Varentsov IM, Sokolova EY, BEAR WG (2003a) Diagnostics and suppression of auroral distortions in the transfer operators of the EM field in the BEAR experiment. Izvestya Phys Solid Earth 39(4):283-307

Varentsov IM, Sokolova EY, Martanus ER, Nalivaiko KV, BEAR WG (2003b) System of EM field transfer operators for the BEAR array of simultaneous soundings: methods and results. Izvestya Phys Solid Earth 39(2):118-148

Vaughan APM, Storey BC (2007) A new supercontinent self-destruct mechanism: evidence from the Late Triassic-Early Jurassic. J Geol Soc Lond 164(2):383-392. https://doi.org/10.1144/001676492005-109

Viljanen A (1996) Source effect on geomagnetic induction vectors in the fennoscandian auroral region. J Geomag Geoelectr 48:1001-1009 
Viljanen A, Prjola R, Hakkinen L (1993) An attempt to reduce induction source effects at high latitudes. J Geomag Geoelectr 45:817-831

Viljanen A, Prjola R, Amm O (1999) Magnetotelluric source effect due to 3D ionosheric current systems using the complex image method for 1D conductivity structures. Earth Planets Space 51:933-945

Viljanen A, Pulkkinen A, Amm O, Pirjola R, Korja T, BEAR Working Group (2004) Fast computation of the geoelectric field using the method of elementary current systems and planar Earth models. Ann Geophys 22:101-113

Vogtli K (1967) DC resistivity soundings on Devon Island and North West Territory, Canada. J Glaciol 6(47):635-642

Wannamaker PE, Stodt JA, Olsen SL (1996) Dormant state of rifting below the Byrd Subglacial Basin, West Antarctica, implied by magnetotelluric (MT) profiling. Geophys Res Lett 23:2983-2986. https://doi.org/10.1029/96g102887

Wannamaker PE, Stodt JA, Olsen SL, Pellerin L, Hall D (2004) Structure and thermal regime beneath the South Pole region, East Antarctica, from magnetotelluric measurements. Geophys J Int 157:36-54

Wannamaker PE, Caldwell TG, Jiracek GR, Maris V, Hill GJ, Ogawa Y, Bibby HM, Bennie SL, Heise W (2009) Fluid and deformation regime of an advancing subduction system at Marlborough, New Zealand. Nature 460:733-736. https://doi.org/10.1038/nature08204

Wannamaker P, Hill G, Stodt J, Maris V, Ogawa Y, Selway K, Boren G, Bertrand E, Uhlmann D, Ayling B, Green AM, Fucht D (2017) Uplift of the central Transantarctic Mountains. Nat Commun. https://doi. org/10.1038/s41467-017-01577-2

Whillans IM (1976) Radio-echo layers and the recent stability of the West Antarctic ice sheet. Nature 264(5582):152-155

Willis JK, Church JA (2012) Regional sea level projection. Science 336:550-551

Winberry JP, Anandakrishnan S (2003) Seismicity and neotectonics of West Antarctica. Geophys Res Lett 30:1931-1935. https://doi.org/10.1029/2003gl018001

Winberry JP, Anandakrishnan S (2004) Crustal structure of the West Antarctic rift system and Marie Byrd Land hotspot. Geology 32(11):977-980. https://doi.org/10.1130/g20768.1

Wishart ER, Radok U (1967) Electrostatic Charging of aerial wires during Antarctic blizzards. Polar Meteorology, Technical Note No. 87, WMO-No. 211.TP.111, World Meteorological Organization, Geneva, pp 492-529

Yamasaki T, Miura H, Nogi Y (2008) Numerical modeling study on the flexural uplift of the Transantarctic Mountains. Geophys J Int 174:377-390

Zandomeneghi D, Barclay A, Almendros J, Godoy JMI, Wilcock WSD, Ben-Zvi T (2009) Crustal structure of Deception Island volcano from P wave seismic tomography: tectonic and volcanic implications. J Geophys Res 114:B06310. https://doi.org/10.1029/2008jb006119

Zandt G, Gilbert G, Owens TJ, Ducea M, Saleeby J, Jones CH (2004) Active foundering of a continental arc root beneath the southern Sierra Nevada in California. Nature 431:41-46

Závada P, Dědeček P, Mach K, Lexa O, Potužák M (2011) Emplacement dynamics of phonolite magma into maar-diatreme structures - correlation of field, thermal modeling and AMS analogue modeling dat. J Volcanol Geotherm Res 201:210-226. https://doi.org/10.1016/j.jvolgeores.2010.07.012

Zhizhin M, Kihn E, Redmon R, Medvedev D, Mishin D (2008) Space physics interactive data resourceSPIDR. Earth Sci Inform 1:79-91

Zonge KL, Hughes LJ (1985) Effect of electrode contact resistance on electric field measurements. In: SEG Annual meeting abstracts, paper MIN 1.5, pp 231-234

Publisher's Note Springer Nature remains neutral with regard to jurisdictional claims in published maps and institutional affiliations.

\section{Affiliations}

\section{Graham J. Hill ${ }^{1,2}$}

1 Institute of Geophysics, Czech Academy of Science, 1401 Bocni II, 14100 Prague 4,

Czech Republic

2 Gateway Antarctica, University of Canterbury, Private Bag 4800, Christchurch 8140, New Zealand 